\title{
Naturalne i antropogeniczne przekształcenia środowiska geograficznego na stanowisku archeologicznym kultury mogilowej w Szczepidle 17 (Kotlina Kolska)
}

\author{
Natural and anthropogenic transformation of the geographical environment at the \\ archeological site of the Tumulus culture at Szczepidło 17 (the Koło Basin)
}

\author{
Iwona Hildebrandt-Radke ${ }^{1}$, Przemysław Makarowicz ${ }^{2}$ \\ ${ }^{1}$ Instytut Geoekologii i Geoinformacji, Uniwersytet im. Adama Mickiewiczaw Poznaniu, hilde@amu.edu.pl \\ ${ }^{2}$ Instytut Prahistorii, Uniwersytet im. Adama Mickiewicza w Poznaniu
}

\begin{abstract}
Zarys treści: Artykuł dotyczy badań relacji człowiek-środowisko na przykładzie osady kultury mogiłowej ze środkowej epoki brązu, którą odkryto na obszarze niecki deflacyjnej pomiędzy wydmami parabolicznymi na odcinku konińskim Pradoliny Warty. Lokalizacji osadnictwa kultury mogiłowej w pradolinie sprzyjały warunki klimatyczne okresu subborealnego, które określane są jako suche i chłodne. W wyniku badań archeologicznych, litologicznych i geochemicznych stwierdzono, że działalność człowieka przekształciła rzeźbę stanowiska archeologicznego, czyli niecki deflacyjnej. Powstały obiekty archeologiczne, które są pozostałościami działalności osadniczej i gospodarczej (metalurgicznej) zachodzącej na tych samych przestrzeniach stanowiska wielokrotnie. Archiwalne badania palinologiczne wskazują na: obecność wskaźników synantropizacji środowiska, gatunków wprowadzanych przez człowieka, ale też pośrednio na wylesienia, pojawiają się powierzchnie otwarte - pola. Od okresu subborealnego można obserwować nakładanie się wpływów antropogenicznych i naturalnych, klimatycznych kształtujących reżim hydrologiczny w dolinie Warty - można wnioskować o coraz większej częstotliwości powodzi i akumulacji mad. Ten czynnik w konsekwencji mógł się przyczynić do opuszczenia osady około 2800 BP (okres wilgotnych warunków w dolinie).
\end{abstract}

Słowa kluczowe: Pradolina Warty, procesy eoliczne, kultura mogiłowa, epoka brązu, metalurgia

\begin{abstract}
This article focuses on man-environment relations as exemplified by a Tumulus culture settlement from the Middle Bronze Age discovered in a deflation basin among parabolic dunes in the Konin section of the Warta Pradolina. What favoured the location of the Tumulus culture settlement in the Pradolina was the climatic conditions of the Subboreal period: dry and cool. As archeological, lithological and geochemical studies have shown, human activity has transformed the relief of the archeological site, i.e. the deflation basin. There have appeared archeological objects which are remnants of settlement and economic (metallurgical) activities taking place many times in the same places of the site. Archival palynological research suggests synanthropisation of the environment, the presence of species introduced by man and, indirectly, deforestation: there appeared open spaces - fields. From the Subboreal stage on, one can observe a joint impact of anthropogenic and natural (climatic) factors on the hydrological regime pattern in the Warta valley: a growing frequency of floods and an accumulation of muds. This factor could in effect force people to abandon the settlement about $2800 \mathrm{BP}$ (a period of humid conditions in the valley).
\end{abstract}

Key words: Warta Pradolina, aeolian processes, Tumulus culture, Bronze Age, metallurgy

\section{Wprowadzenie}

Badania realizowane w Szczepidle pozwoliły na odkrycie rozległej osady otwartej należącej do kultury mogiłowej ze środkowej epoki brązu. Specyficzna lokalizacja sta- nowiska na pograniczu kilku jednostek krajobrazowych zrodziła pytanie, jaką rolę mogło odgrywać środowisko geograficzne w ocenie atrakcyjności osadniczej tego miejsca oraz w jakim stopniu tak rozległe i intensywne użytkowanie terenu wpłynęło na naturalne procesy geo- 
dynamiczne, m.in. reaktywację procesów eolicznych w holocenie.

Czynnikiem, który ogranicza możliwości poznawcze w zakresie pradziejowej działalności człowieka na badanym obszarze, jest przede wszystkim intensywna współczesna antropopresja. Składają się na nią: wielkoprzestrzenne górnictwo odkrywkowe węgla brunatnego, liczne współczesne melioracje, budowa sztucznych zbiorników wodnych itp. W obrębie pradoliny w największej skali zaznaczają się zmiany w zakresie hydrologii prowadzące do odwodnienia obszaru.

\section{Charakterystyka kultury mogiłowej oraz główne rezultaty badań archeologicznych osady w Szczepidle}

Kultura mogiłowa jest jedną ze słabiej zbadanych kultur archeologicznych rozwijających się w epoce brązu. Swym zasięgiem na terytorium współczesnej Polski obejmowała niemal cały Śląsk, znaczne obszary Wielkopolski, a poza granicą także wschodnią część Brandenburgii. W jej rozwoju wyróżnia się obecnie trzy zasadnicze fazy:

- najstarszą z nich, datowaną na początek II okresu epoki brązu (B1 - od 1600 BC),

- młodszą, przypadającą na środkową i młodszą część tego okresu, czyli fazę klasyczną (B2-C1),

- najmłodszą, datowaną na sam schyłek II i początek III okresu epoki (C2-D do 1200 BC) (Gedl 1989).

Kultura mogiłowa wyróżnia się cechami obrządku pogrzebowego. Stosowano pochówek szkieletowy, a zmarłych chowano głównie w postaci wyprostowanej. Typową formą grobu był usypany z ziemi kurhan wzmocniony wewnętrzną konstrukcją kamienną, która składała się z jądra ułożonego nad centralnym pochówkiem oraz wieńca okalającego kurhan po zewnętrznej stronie nasypu nagrobnego. Specyfiką gospodarki w tym okresie były wyroby metalurgiczne (głównie $\mathrm{z}$ brązu), typowe wyłącznie dla kultury mogiłowej (np. duże szpile z charakterystycznymi główkami) (por. Gedl 1989). Dominującą rolę w gospodarce wczesnej fazy kultury mogiłowej odgrywała hodowla zwierząt o charakterze pasterskim, ale z czasem, tak jak i na innych obszarach tej kultury, rosło znaczenie upraw.

W odróżnieniu od obrządku pogrzebowego słabiej poznane są osady, co może świadczyć, że albo nie było stabilnego osadnictwa, albo nie zostały dotąd rozpoznane z uwagi na preferowanie badań spektakularnych cmentarzysk. Lukę tę może uzupełnić odkryta w połowie lat 90. XX w. osada kultury mogiłowej w Szczepidle (Makarowicz, Garbacz-Klempka 2014). Na terenie osady odnaleziono wiele źródeł ruchomych (ceramiki, narzędzi kamiennych i krzemiennych, kości zwierzęcych, żużla, półfabrykatów oraz gotowych wyrobów z brązu). Odkryto tam aż 291 obiektów nieruchomych, takich jak: jamy gospodarcze i śmietnikowe, piwniczki, paleniska, a nawet pozostałości zabudowania mieszkalno-produkcyjnego, które przypisywane są osadnictwu przedstawicieli kultury mogiłowej. Zabudowania gospodarcze charakteryzowały się owalnym kształtem w planie, natomiast trapezowatym w przekroju pionowym. Jamy śmietniskowe koncentrowały się w północnej części osady, a warstwowane wypełniska wskazują na ich wielokrotne wykorzystywanie. Najbardziej spektakularnym odkryciem jest jednak pozostałość po zabudowaniu mieszkalno-gospodarczym, które pełniło funkcję warsztatu metalurgicznego. Znaleziono w nim ceramikę naczyniową, polepę, żużel brązowy, a także gotowe wyroby brązowe i złom, co jest pierwszym tego typu odkryciem w nieobronnej osadzie kultury mogiłowej w Europie Środkowej (Makarowicz 2007). Potwierdza to tezę postawioną przez Kostrzewskiego (1953), że jednym z najważniejszych zajęć gospodarczych ludności kultury mogiłowej była obróbka brązu.

\section{Położenie geograficzne stanowiska archeologicznego}

Obszar stanowiska archeologicznego w podziale fizycznogeograficznym Polski należy do podprowincji Niziny Środkowopolskie (318) oraz makroregionu Nizina Południowopolska (318.1). Od północnego zachodu i północnego wschodu sąsiadują z Niziną Południowopolską Pojezierze Gnieźnieńskie (315.54) i Pojezierze Kujawskie (315.57) należące do makroregionu Pojezierze Wielkopolskie (315.5) (Kondracki 1998) (ryc. 1). W podziale Niziny Południowopolskiej (318.1) na badanym obszarze wyróżnić można Dolinę Konińską (318.13), Kotlinę Kol-

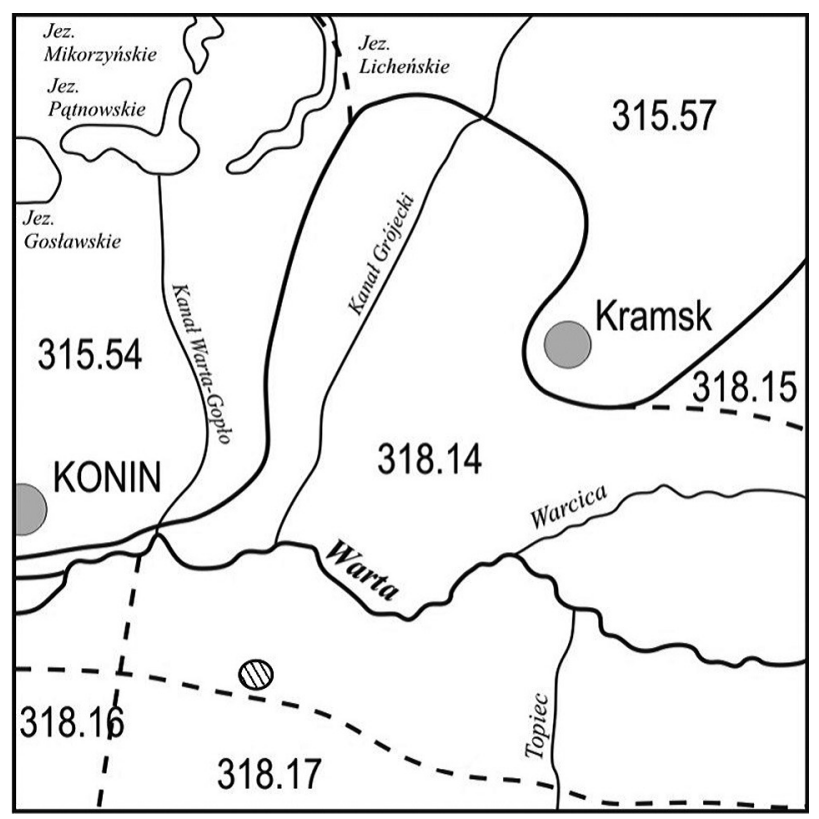

Ryc. 1. Podział fizycznogeograficzny obszaru badań (Kondracki 1998). Numeracja regionów w tekście. Obszar zaszrafowany oznacza lokalizację stanowiska archeologicznego

Fig. 1. Physical-geographic division of the study area (Kondracki 1998). Numeration of regions in the text. The hachured area shows the location of the archeological site 
ską (318.14), Wysoczyznę Kłodawską (318.15), Równinę Rychwalską (318.16) i Wysoczyznę Turecką (318.17). Stanowisko archeologiczne położone jest w obrębie rozległej jednostki nazywanej Kotliną Kolską. Według podziału geomorfologicznego Niziny Wielkopolskiej obszar będący przedmiotem badań leży w regionie Pradoliny Warszawsko-Berlińskiej, w obrębie subregionu o nazwie Odcinek Koniński (Krygowski 1961).

\section{Metody badań}

Główną metodą rozpoznania stanowiska archeologicznego były badania terenowe. Ich podstawą była eksploracja wykopaliskowa prowadzona $\mathrm{z}$ różnym natężeniem od połowy lat 90. XX w. pod kierunkiem jednego ze współautorów. Łącznie po dziesięciu sezonach na 35,5 ara zbadanych wykopaliskowo odnotowano: 291 obiektów nieruchomych, 20856 fragmentów ceramiki, 1019 wyrobów krzemiennych (w tym grociki strzał), 1442 wyroby kamienne (w tym kilka narzędzi cyzelerskich, gładzików,

m n.p.m.

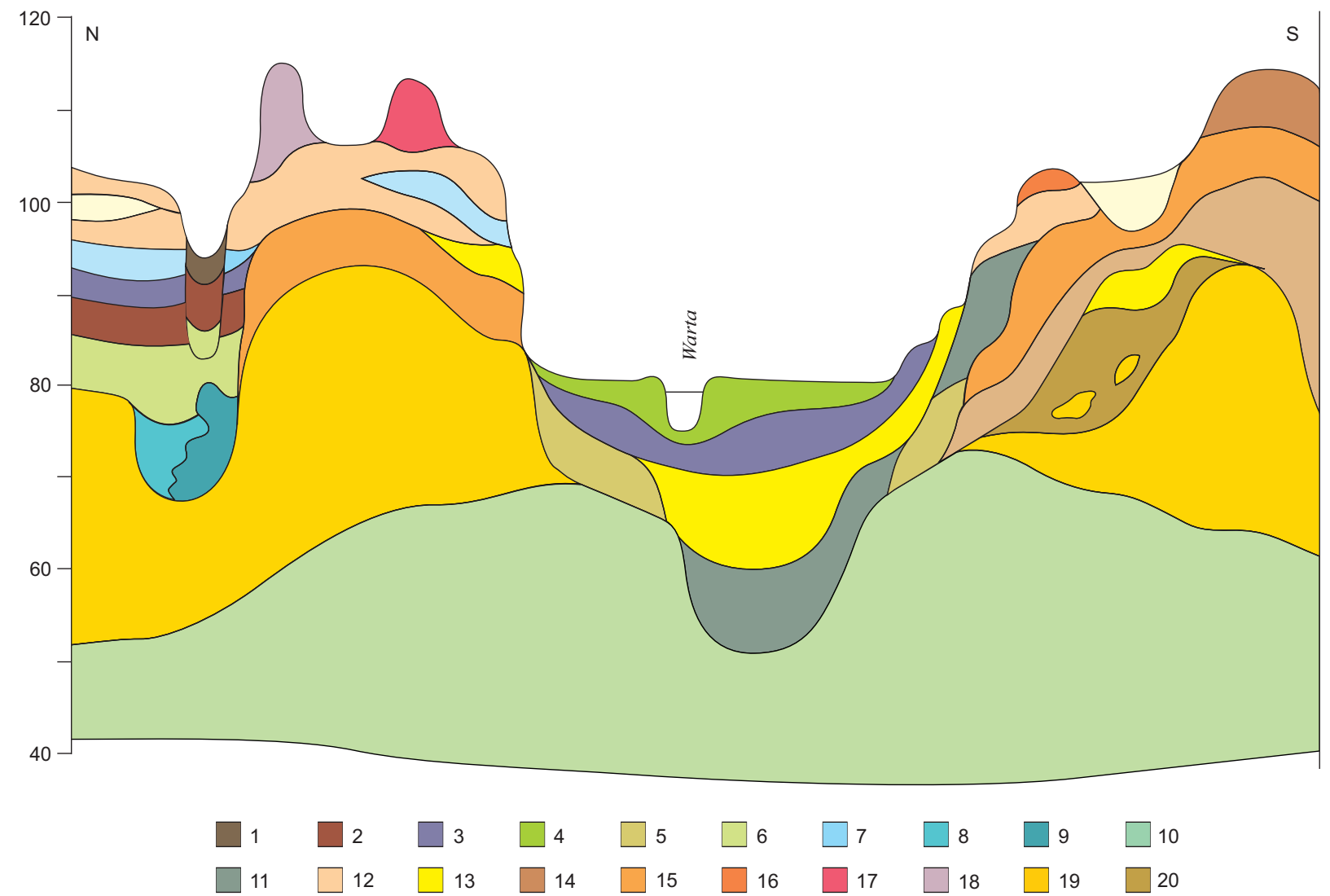

Ryc. 2. Syntetyczny przekrój geologiczny przez centralną pradolinę Warty (za Mańkowską 1974)

1 - torfy holoceńskie, 2 - torfy i gytie ze zlodowacenia północnopolskiego, piaski i żwiry rzeczne - zlodowacenie północnopolskie, 3 - piaski i żwiry rzeczne ze zlodowacenia północnopolskiego, 4 - piaski rzeczne holoceńskie, 5 - piaski rzeczne ze zlodowacenia środkowopolskiego, 6 - mułki i piaski jeziorne związane ze zlodowaceniem północnopolskim, 7 - iły, mułki i piaski zastoiskowe - ze zlodowacenia północnopolskiego, 8 - deluwia ze zlodowacenia północnopolskiego, 9 - osady rezydualne ze zlodowacenia północnopolskiego, 10 - osady kredy w podłożu geologicznym, 11 - osady rzeczne interglacjału emskiego, 12 - glina zwałowa zlodowacenia północnopolskiego, 13 - piaski fluwioglacjalne zlodowacenia północnopolskiego, 14 - morena czołowa ze zlodowacenia środkowopolskiego, 15 - gliny zwałowe ze zlodowacenia środkowopolskiego, 16 - piaski i żwiry lodowcowe ze zlodowacenia północnopolskiego, 17 - osady moren czołowych ze zlodowacenia północnopolskiego, 18 - ozy ze zlodowacenia północnopolskiego, 19 - osady trzeciorzędowe ze zlodowacenia północnopolskiego, 20 - glina zwałowa ze zlodowacenia południowopolskiego zaburzona glacitektonicznie

Fig. 2. Synthetic geological cross-section through the central Warta Pradolina (after Mańkowska 1974)

1 - Holocene peats, 2 - peats and gyttjas of North Polish Glaciation, fluvial sands and gravels of North Polish Glaciation, 3 - fluvial sands and gravels of North Polish Glaciation, 4 - Holocene fluvial sands, 5 - fluvial sands of Central Polish Glaciation, 6 - lacustrine silts and sands associated with North Polish Glaciation, 7 - glacio-lacustrine clays, silts and sands of North Polish Glaciation, 8 colluvia of North Polish Glaciation, 9 - residual deposits of North Polish Glaciation, 10 - chalk deposits in geological substratum, 11 - fluvial deposits of Eemian Interglacial Stage, 12 - tills of North Polish Glaciation, 13 - fluvioglacial sands of North Polish Glaciation, 14 - end moraine of Central Polish Glaciation, 15 - tills of Central Polish Glaciation, 16 - sands and gravels of North Polish Glaciation, 17 - end-moraine deposits of North Polish Glaciation, 18 - eskers of North Polish Glaciation, 19 - Tertiary deposits of North Polish Glaciation, 20 - glaciotectonically disturbed tills of South Polish Glaciation 


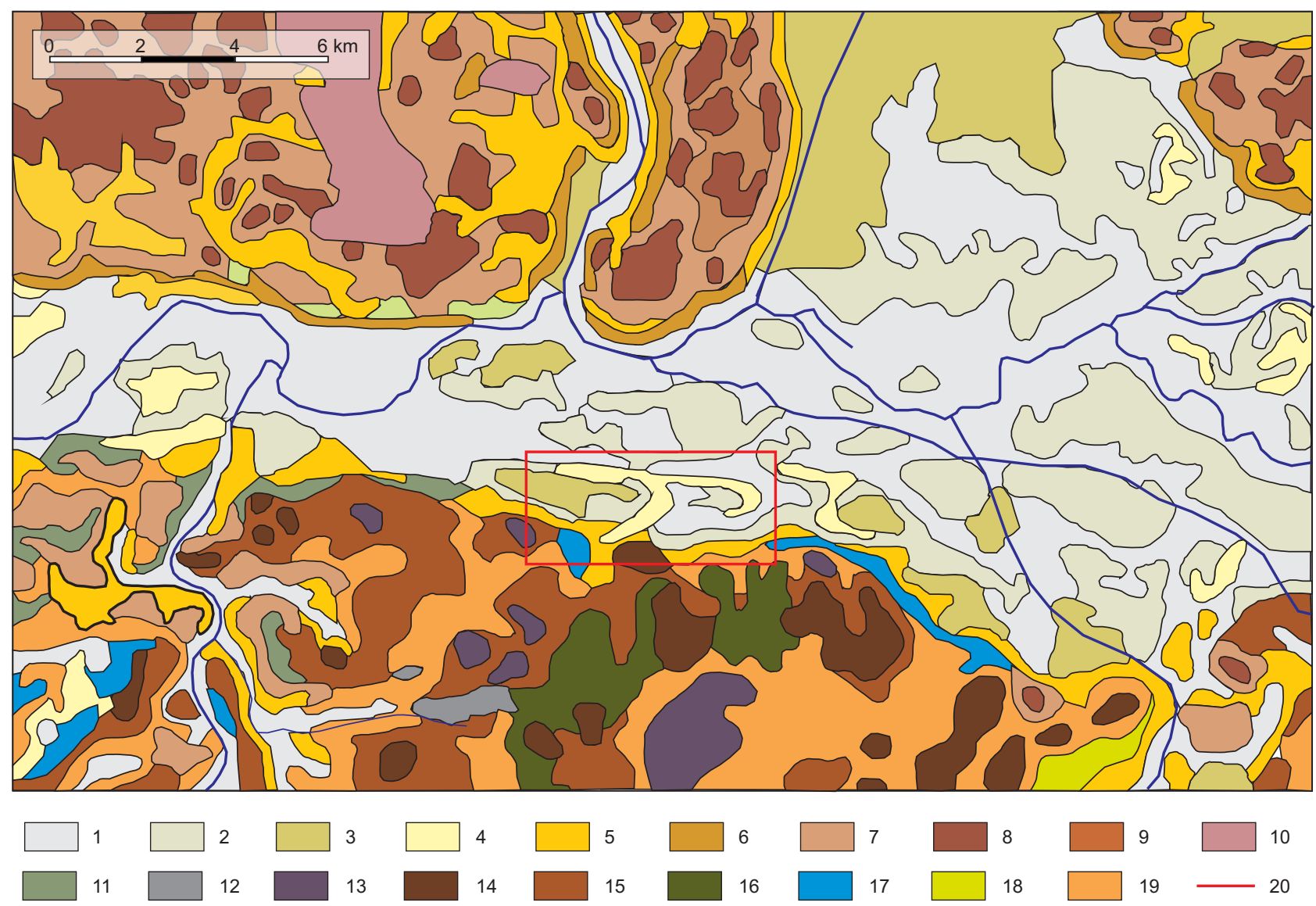

Ryc. 3. Obszar badań na tle fragmentu mapy geologicznej utworów powierzchniowych (za Mańkowską 1974)

1 - osady rzeczne holoceńskie, 2 - osady rzeczne, zlodowacenie północnopolskie, 3 - torfy holoceńskie, 4 - osady eoliczne - późny glacjał i holocen, 5 - osady fluwioglacjalne, zlodowacenie północnopolskie, 6 - glina zwałowa zlodowacenia środkowopolskiego na północ od pradoliny, 7 - glina zwałowa zlodowacenia środkowopolskiego, 8 - osady moren czołowych ze zlodowacenia północnopolskiego, 9 - gliny lodowcowe, zlodowacenie północnopolskie, 10 - obszary zdegradowane górnictwem odkrywkowym, 11 - osady fluwialne interglacjału eemskiego, 12 - namuły holoceńskie, 13 - gliny, piaski i żwiry zlodowacenia środkowopolskiego, 14 - osady moren czołowych zlodowacenia środkowopolskiego, 15 - glina zwałowa zlodowacenia środkowopolskiego na południe od pradoliny, 16 - osady kemowe ze zlodowacenia środkowopolskiego, 17 - osady zastoiskowe ze zlodowacenia środkowopolskiego, 18 - osady fluwioglacjalne ze zlodowacenia północnopolskiego na południe od pradoliny, 19 - osady fluwioglacjalne ze zlodowacenia środkowopolskiego, 20 - obszar badań

Fig. 3. Study area against the background of a fragment of the geological map of surficial deposits (after Mańkowska 1974)

1 - Holocene fluvial deposits , 2 - fluvial deposits, North Polish Glaciation, 3 - Holocene peats, 4 - aeolian deposits, Late Glacial and Holocene, 5 - fluvioglacial deposits, North Polish Glaciation, 6 - tills of Central Polish Glaciation north of Pradolina, 7 - tills of Central Polish Glaciation, 8 - end-moraine deposits of North Polish Glaciation, 9 - tills, North Polish Glaciation, 10 - areas degraded by open-cast mining, 11- fluvial deposits of Eemian Interglacial Stage, 12 - Holocene muds, 13 - tills, sands and gravels of Central Polish Glaciation, 14 - end-moraine deposits of Central Polish Glaciation, 15 - tills of Central Polish Glaciation south of Pradolina, 16 - kame deposits of Central Polish Glaciation, 17 - glacio-lacustrine deposits of Central Polish Glaciation, 18 - fluvioglacial deposits of North Polish Glaciation south of Pradolina, 19 - fluvioglacial deposits of Central Polish Glaciation, 20 - study area

żaren, rozcieraczy, płyt szlifierskich, fragmenty i całe egzemplarze toporków i siekier), 55 fragmentów polepy, 175 kości zwierzęcych, 134 przedmioty z brązu: gotowe wyroby (trzy szpile, siedem grocików strzał, fragmenty bransolet, grotu, nożyka, ozdób), półproduktów (drut) i złomu (trzy duże bryłki wytopionego brązu, zlewki wytopki), 89 bryłek żużla brązowego, fragmenty kilku tygli glinianych i łyżki odlewniczej oraz ciężarka tkackiego.

W roku 2011 poszerzono zakres badań o rozpoznanie geomorfologiczne, litologiczne i geochemiczne stanowiska, pobierając próby z profili wykopów, z profili lub z pojedynczych warstw z obiektów. Dodatkowo wykonano dwa odwierty w dystalnej części wydmy parabolicznej
Szczepidle, których celem była obserwacja potencjalnej reaktywacji procesów eolicznych. Próbki osadów pobrane w czasie badań terenowych poddano analizom laboratoryjnym. Wstępnych analiz litologicznych osadów powierzchniowych dokonano na podstawie dwóch próbek pobranych w trakcie badań wykopaliskowych. Jednej z warstwy próchniczej (próbka 1) oraz drugiej z osadów eolicznych (próbka 2). Charakterystyki obiektów archeologicznych dokonano, analizując 48 próbek pobranych ${ }^{1}$ $\mathrm{z}$ różnych części stanowiska oraz poziomów stratygra-

Analizy zostały przeprowadzone w laboratorium Zakładu Geologii i Paleogeografii Czwartorzędu Uniwersytetu im. Adama Mickiewicza w Poznaniu. 
ficznych tych obiektów. Skład granulometryczny próbek zbadano metodą analizy sitowej, przesiewając 41-gramowe próbki przez zestaw sit o standaryzowanych wielkościach oczek. Podstawowe parametry uziarnienia w skali phi obliczono na podstawie wzorów Folka, Warda (Racinowski i in. 2001) w programie GRADISTAT wersja 4.0 (Blott, Pye 2001).

Dodatkowo oznaczono zawartość materii organicznej oraz węglanu wapnia. Preparatyka próbek polegała na ich ponownym wysuszeniu, a następnie odważeniu na wadze analitycznej (z dokładnością do 0,00001g) około 1 grama materiału $\mathrm{z}$ każdej próbki. Materiał prażono w piecu muflowym w temperaturze $550^{\circ} \mathrm{C}$ przez okres 4 godzin. Ostudzone próbki jeszcze raz zważono i na podstawie różnicy wag przed ważeniem i po określono procentową zawartość materii organicznej. By oszacować zawartość węglanu wapnia, próbki ponownie wyprażono w temperaturze $950^{\circ} \mathrm{C}$ przez okres 2 godzin i jeszcze raz ustalono różnicę wag.

W analizach geochemicznych ${ }^{2}$ osadów oznaczono zarówno skład pierwiastków głównych, jak i śladowych. Ekstrakcji pierwiastków śladowych dokonywano w wodzie królewskiej według normy ISO 11466, a następnie wykonano przesącza do kolb miarowych na 100 ml. Pierwiastki takie, jak: miedź, cynk, mangan, żelazo, ołów, nikiel, chrom, oznaczane były metodą atomowej absorpcji spektrometrycznej w płomieniu acetylenowym (ASA), potas metodą emisyjnej spektrometrii atomowej w płomieniu acetylen-powietrze (ESA), natomiast wapń w płomieniu acetylen-podtlenek azotu. Fosfor oznaczono kolorymetrycznie z molibdenianem amonu.

\section{Budowa geologiczna starszego podłoża oraz charakterystyka osadów czwartorzędu}

Analizowany obszar leży w obrębie jednostki geologicznej nazywanej niecką mogileńsko-łódzką. W głębszym podłożu, na seriach związanych z orogenezą waryscyjską, zalegają osady permskie i mezozoiczne. Formacja mezozoiczna zapada się z południa na północ, w okolicy Konina przybierając postać wyraźnej elewacji (ryc. 2). Zróżnicowanie powierzchni mezozoicznej jest efektem tektoniki oraz paleogeńskiej i neogeńskiej denudacji. Przykrywa ją zwarta powłoka utworów, w których skład wchodzą osady oligocenu, miocenu i pliocenu. Zaliczyć do nich można serie burowęglowe w postaci węgla brunatnego eksploatowane odkrywkowo w wielu miejscach tego obszaru. Ukształtowanie podłoża podczwartorzędowego miało wpływ na miąższość utworów glacjalnych, które są bardziej masywne w miejscach obniżeń w podłożu mezozoicznym.

Plejstocen reprezentowany jest przez osady glacjalne i glacifluwialne składające się z glin zwałowych, piasków,

Oznaczenia składu geochemicznego wykonane zostały w Katedrze Gleboznawstwa Uniwersytetu Przyrodniczego w Poznaniu. żwirów i mułków (ryc. 3). Budowa analizowanego obszaru związana jest $\mathrm{z}$ depozycją osadów lodowcowych i fluwioglacjalnych zlodowacenia północnopolskiego i środkowopolskiego. Miąższość osadów czwartorzędu jest zróżnicowana i wynosi od $8 \mathrm{~m} \mathrm{w}$ dolinie Warty do $100 \mathrm{~m}$ w obrębie Złotej Góry. Górne warstwy plejstocenu budują dwie warstwy glin: brązowa ze zlodowacenia północnopolskiego i szara ze zlodowacenia środkowopolskiego.

Budowa serii czwartorzędowych jest na tyle skomplikowana, że do lat 90. XX w. obszar leżący na północ od Pradoliny Warty zaliczany był do młodoglacjalnego, ukształtowanego przez zlodowacenie północnopolskie, natomiast na południe od pradoliny - do staroglacjalnego, ukształtowanego przez zlodowacenie środkowopolskie (Kłysz 1981, Stankowski, Krzyszkowski 1991, Stankowski i in. 1995) (por. także ryc. 4). W najnowszych opracowaniach, szczególnie na Mapie Geologicznej publikowanej przez PIG (Marks i in. 2006), najstarsza faza zlodowacenia północnopolskiego, czyli faza leszczyńska, zaznaczona jest $\mathrm{w}$ postaci lobu sięgającego na południe od Konina, obejmującego teren wysoczyzny na południe od Pradoliny Warty (ryc. 4). Obszerniejszego przeglądu poglądów na temat przebiegu zasięgu zlodowacenia północnopolskiego dokonali wcześniej Petera, Forysiak (2003). Oznacza to młodoglacjalny wiek np. Pagórków Złotogórskich, znajdujących się na południe od badanego stanowiska. Inna jest też interpretacja genetyczna wielu form po stronie południowej pradoliny.

Jedną z ważniejszych form badanego obszaru jest pradolina, która równoleżnikowo rozdziela omawiany teren. Powstała ona w schyłkowej części fazy poznańskiej ostatniego zlodowacenia. Jest to oś drenażu obszaru, do której uchodzą inne cieki. Do południowej strony pradoliny, przy której zlokalizowane jest stanowisko archeologiczne, nawiązują: Kanał Główny, kanał Powa-Topiec i Topiec, natomiast od północy Kanał Ślesiński (Warta-Gopło), Kanał Grójecki i Warcica. Odcinek pradoliny zajmują największe tereny podmokłe. Dno pradoliny Warty oraz terasy zbudowane są z osadów rzecznych i jeziornych, takich jak: piaski, mułki i torfy, zarówno holoceńskich, jak

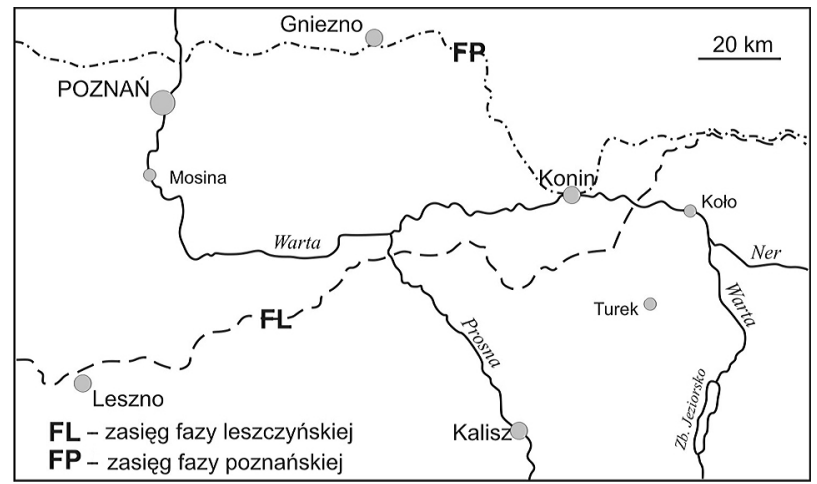

Ryc. 4. Maksymalne zasięgi fazy leszczyńskiej i poznańskiej na badanym obszarze w świetle najnowszych badań (Marks i in. 2006, Widera 2009)

Fig. 4. Maximum extents of the Leszno and Poznań Stages in the study area in the light of the latest research (Marks et al. 2006, Widera 2009) 
i związanych z ostatnim zlodowaceniem - fazami leszczyńską i poznańską. Na powierzchniach piaszczystych w późnym glacjale rozwinęła się działalność eoliczna. Na południe od pradoliny rozciąga się strefa moren czołowych, które według najnowszych ustaleń należy w znacznej mierze zaliczyć do fazy leszczyńskiej. Obszar znajdujący się w zasięgu fazy leszczyńskiej zajmują zarówno osady glacjalne, fluwioglacjalne, jak i zastoiskowe. W tej strefie, w obrębie Pagórków Złotogórskich, znajdują się najwyższe wzniesienia tego obszaru wynoszące $191 \mathrm{~m}$ n.p.m. Na północ od pradoliny rozpościera się strefa czołowomorenowa fazy poznańskiej zlodowacenia północnopolskiego (maksymalna wysokość na terenie objętym analizą wynosi $115 \mathrm{~m}$ n.p.m.).

\section{Morfometria, litologia i geomorfologia stanowiska archeologicznego}

Powierzchnia terenu w otoczeniu stanowiska archeologicznego należy do bardzo urozmaiconych. Wpływ na to miały czwartorzędowa geneza tego obszaru oraz współczesna historia górnictwa odkrywkowego. Na terenach z rzeźbą nie zmienioną przez eksploatację węgla brunatnego deniwelacja w obrębie płatów wysoczyznowych wynosi od 9-27 m do nawet $109 \mathrm{~m} \mathrm{w}$ rejonie Złotej Góry (Kozacki i in. 2004). Na obszarze objętym opraco- waniem można wyróżnić następujące zespoły form rzeźby terenu (ryc. 3):

- wysoczyznę morenową - formę płaską, występującą po północnej stronie doliny Warty zbudowana z glin, piasków i żwirów;

- moreny czołowe typu akumulacyjnego z fazy poznańskiej zlodowacenia północnopolskiego po północnej stronie doliny Warty w pobliżu Konina, uformowane podczas fazy leszczyńskiej tego zlodowacenia po południowej stronie doliny Warty; linie maksymalnego zasięgu obu faz łączą się w rejonie Grójca, tworząc wspólną strefę wzniesień morenowych (od Konina w kierunku Stefanowa);

- sandry - zajmują niewielki odsetek powierzchni po stronie północnej doliny Warty (pomiędzy Pątnowem i Helenowem), natomiast tworzą rozległe powierzchnie po południowej stronie doliny Warty w otoczeniu masywu złotogórskiego;

- rynny glacjalne - formy rozcinające wysoczyznę morenową, dna rynien wypełniają holoceńskie piaski, żwiry rzeczne oraz torfy, w rynnach występują jeziora,

- zbiorniki zastoiskowe - powstałe w obniżeniach terenu, wypełnione iłami, mułkami i piaskami, współcześnie w formie kopalnej;

- Pradolinę Warszawsko-Berlińską - formę utworzoną w schyłku fazy poznańskiej ostatniego zlodowacenia, poligenetyczną, założoną w miejscu kopalnej formy wklęsłej.

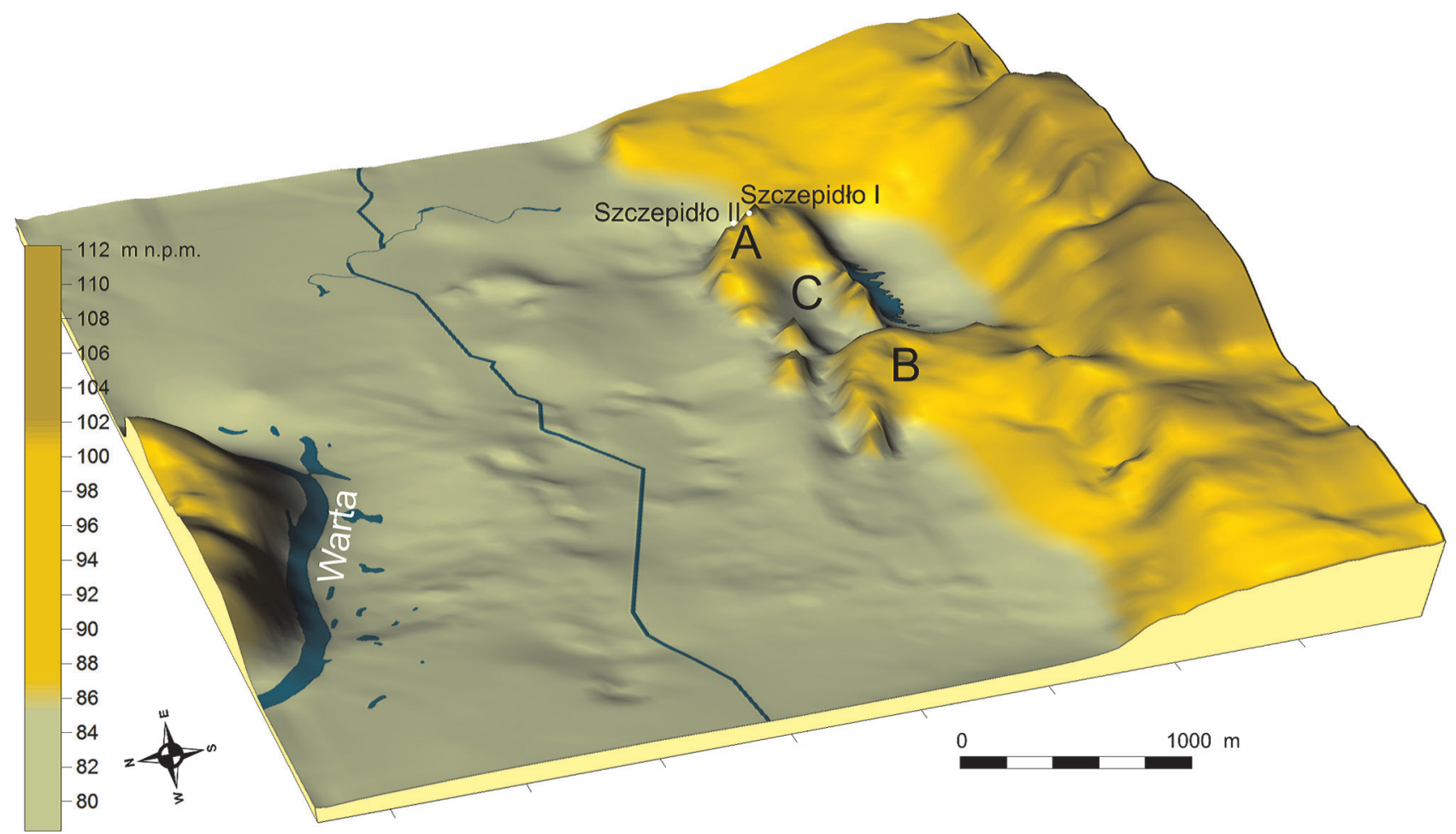

Ryc. 5. Lokalizacja położenia wydm parabolicznych w Pradolinie Warty na numerycznym modelu rzeźby terenu

A - wydma w Szczepidle, B - wydma w Machniaczu, C - lokalizacja stanowiska archeologicznego

Fig. 5. The location of parabolic dunes in the Warta Pradolina on the digital elevation model A - dune at Szczepidło, B - dune at Machniacz, C - location of the archeological site 


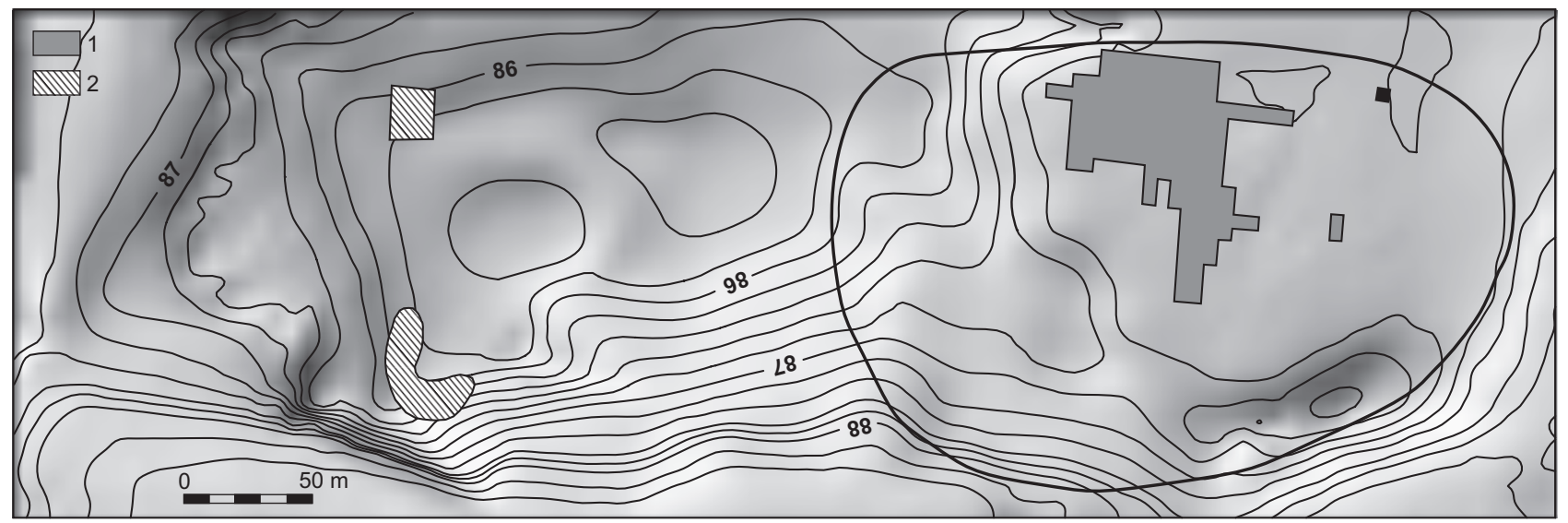

Ryc. 6. Morfometria stanowiska archeologicznego w Szczepidle (wysokości w m n.p.m.)

1 - zasięg wykopów archeologicznych, 2-sztuczne zbiorniki wodne

Fig. 6. Morphometry of the Szczepidło archeological site (altitudes in metres a.s.1.)

1 - range of archeological pits, 2-artificial water bodies

Dno pradoliny wyścielają piaski o miąższości 5-10 m. Na terasach wyższych, szczególnie środkowej, występują wydmy o wysokościach względnych do 12 m (Kozacki 1972).

Stanowisko archeologiczne nr $17 \mathrm{w}$ Szczepidle położone jest w południowej, przykrawędziowej części Pradoliny Warty. Obszar ten leży na rzędnej około $85 \mathrm{~m}$ n.p.m. Jest to fragment terasy nadzalewowej, w tym miejscu klasyfikowanej za Trzeciakowskim (1964) jako terasa środkowa (ryc. 5). Terasa środkowa wyniesiona jest ponad koryto Warty na wysokość od 4,5 do 10 m (rzędne 82-88 m n.p.m.). Poniżej niej znajduje się terasa zalewowa, położona na wysokości od 1,5 do $3 \mathrm{~m}$ ponad poziomem dna doliny (rzędne 75,5-80,5 m n.p.m.). Występuje ona w sposób nieciągły po obu stronach Warty i składa się $\mathrm{z}$ dwóch poziomów: niższego, zbudowanego $\mathrm{z}$ mad i torfów, oraz wyższego, zbudowanego z utworów piaszczystych. Terasa wysoka na analizowanym odcinku doliny jest bardzo słabo czytelna (Trzeciakowski 1964).

Na terasie środkowej występują dwie wyraźne formy wydmowe o kształcie parabolicznym. Formą większą i wyższą jest wydma w Machniaczu wysunięta bardziej w kierunku zachodnim. Wysokości bezwzględne osiągają w części kulminacyjnej tej wydmy 106,6 m n.p.m. Maksymalne deniwelacje pomiędzy wierzchołkiem wydmy a powierzchnią terasy dochodzą do $19 \mathrm{~m}$. W kierunku wschodnim od niej rozwinęła się druga, niższa wydma paraboliczna, nazywana wydmą w Szczepidle, w najwyższym punkcie osiągająca 95,4 m n.p.m. Deniwelacja w obrębie tej formy wynosi około $12 \mathrm{~m}$. Obie wydmy powstały pod wpływem wiatrów wiejących z kierunków zachodnich. Pomiędzy ramionami tej wydmy w Szczepidle powstało obniżenie o charakterze niecki deflacyjnej. Teren jest w tym miejscu podmokły, a nadmiar wody odprowadza ciek przepływający po stronie wschodniej wydmy w Machniaczu, a po zachodniej stronie wspomnianej niecki deflacyjnej. Współcześnie wody z tego cieku odprowadzane są do sztucznych zbiorników znajdujących się po południowej stronie wydmy w Szczepidle. Niecka deflacyjna pomiędzy ramionami wydmy w Szczepidle charakteryzuje się zróżnicowaną morfometrią. W części zachodniej teren cechuje się niższym położeniem i jest podmokły. Natomiast wschodnia, nieco wyżej usytuowana część jest sucha, zbudowana z osadów eolicznych i osłonięta ramionami wydmy parabolicznej, z tym że południowe ramię jest dużo słabiej zachowane. Znaczny stopień zniszczenia tej części wydmy jest zapewne wynikiem wykopania nieopodal dużego zbiornika wodnego w czasach współczesnych. Ten właśnie obszar, pomiędzy ramionami wydmy, stał się miejscem lokalizacji otwartej osady ludności kultury mogiłowej (ryc. 6).

$\mathrm{Na}$ podstawie licznych badań terenów wydmowych Wielkopolski geneza tak dużych form wydmowych jest stosunkowo dobrze poznana. Większość badaczy wiąże powstanie tych form z zimnymi okresami późnego glacjału (Tobolski 1966, Kozarski, Tobolski 1968, Rotnicki 1972, Nowaczyk 1986). W porównaniu do dobrego rozpoznania problematyki eolicznej dla Polski, przykładów tego typu badań z Pradoliny Warszawsko-Berlińskiej, a szczególnie Pradoliny Warty, nie jest dużo, co wynika zapewne $\mathrm{z}$ faktu, że w porównaniu $\mathrm{z}$ innymi młodoglacjalnymi obszarami Polski w regionie badań występuje stosunkowo niewiele wydm i znajdują się one w znacznym rozproszeniu (Krajewski 1977, Nowaczyk 1986). $\mathrm{Z}$ najbliżej położonych względem stanowiska archeologicznego wymienić należy wydmę „,iemierowską”, u ujścia Prosny do doliny Warty w Kotlinie Pyzdrskiej, przebadaną przez Stankowskiego (1959), Tobolskiego (1966), Nowaczyka, Rotnickiego (1972), Nowaczyka (1986). Początek akumulacji miąższej serii eolicznej tej formy Nowaczyk (1986) wiąże z młodszym dryasem. Świadczy o tym datowanie warstwy torfu znajdującej się pod serią eoliczną (10 220 \pm 150 BP Gd-2102). Podobnie datowane są inne wydmy z Pradoliny Warszawsko-Berlińskiej (Czmoń, Świętno, Wilcze, Pomorsko) (por. Nowaczyk 1986). Okresy zimne późnego glacjału sprzyjały procesom eolicznym, gdyż podłoże jeszcze nie było związane pokrywą roślinną. W młodszym dryasie panowała tundra parkowa, w której ważna rolę odgrywały różne gatunki bylin. Seria eoliczna wydmy „ciemierowskiej” 


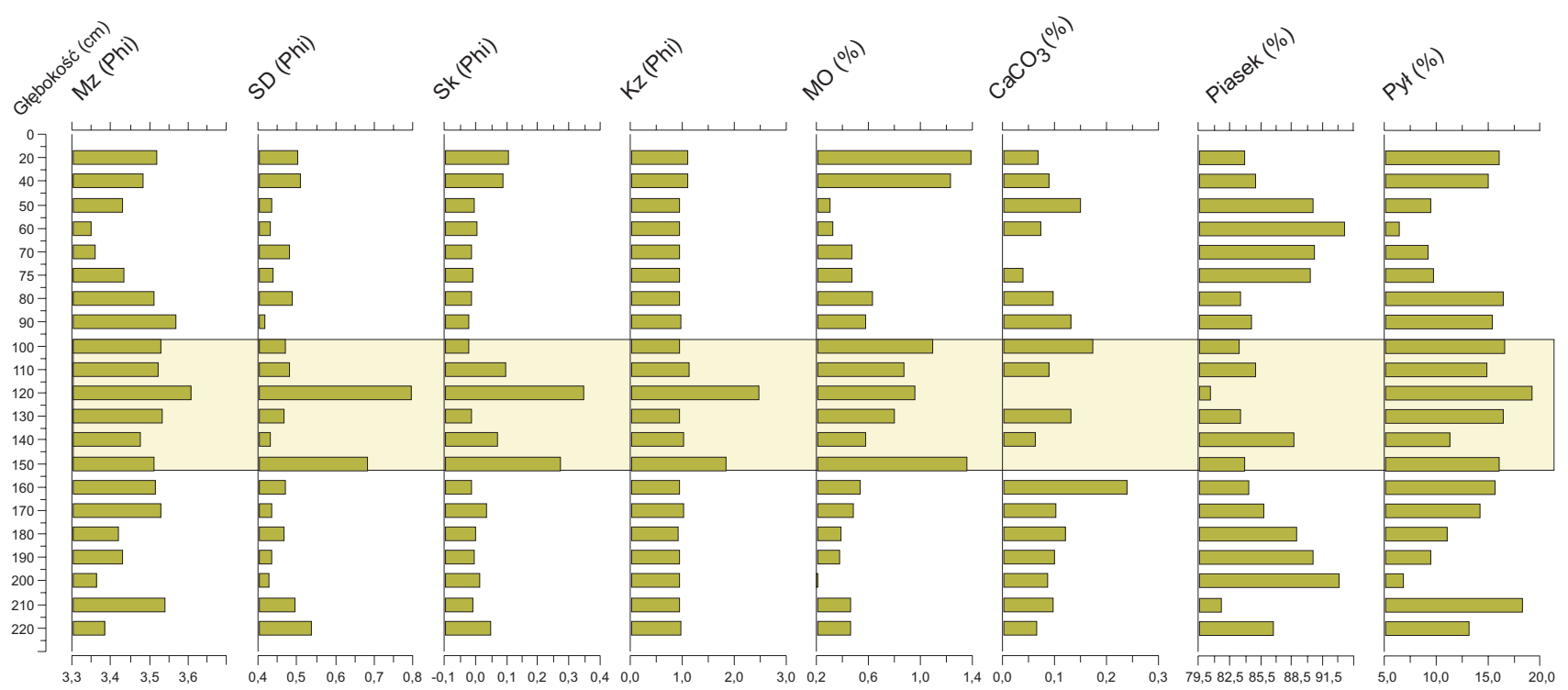

Ryc. 7. Szczepidło II - podstawowe wskaźniki uziarnienia, struktura uziarnienia osadów w procentach oraz udziały procentowe strat prażenia i zawartości węglanów wapnia $\mathrm{z}$ wiercenia w części dystalnej wydmy

Fig. 7. Szczepidło II - basic granulation indices, granulation structure of deposits in per cent, loss-on-ignition percentages, and calcium carbonate content in borehole

rozdzielona jest jednym poziomem gleby kopalnej przechodzącej w niektórych partiach wydmy w torf. Palinologicznie określono przybliżony wiek warstwy na okres subatlantycki (Tobolski 1966). Dominującym kierunkiem formowania się wydm w Polsce, a szczególnie w okresie młodszego dryasu, był sektor wiatrów zachodnich o prędkościach progowych inicjujących transport eoliczny od 4 do $5,5 \mathrm{~m} \mathrm{~s}^{-1}$ (Stankowski 1963, Borówka 1980, Nowaczyk 1986).

Redepozycję holoceńską osadów eolicznych należy wiązać już z działalnością człowieka. Można przypuszczać, że podobną genezę mają wydmy w Machniaczu i Szczepidle, z tym że w ich przypadku etap redepozycji mógł się rozpocząć wcześniej, już w okresie subborealnym (osadnictwo w Szczepidle). W konsekwencji redepozycji nastąiło uruchomienie i usypanie na stokach dystalnych wydm lub płaskich powierzchniach holoceńskich serii eolicznych. O przebiegu holoceńskich procesów eolicznych istnieją dane z wcześniejszego rozpoznania archeologicznego wydmy w Machniaczu. W formie tej, pod nadkładem osadów eolicznych o miąższości 1,5 $\mathrm{m}$, natrafiono na kilka poziomów gleb kopalnych (informacja ustna). Wykonane z kolei dwa wiercenia w części dystalnej wydmy w Szczepidle pozwoliły na uchwycenie jednego słabo zaznaczonego poziomu gleby kopalnej (ryc. 7). Brak odpowiedniego materiału nie pozwolił na jej wydatowanie. Jednak intensywność zasiedlenia niecki deflacyjnej wydmy w Szczepidle oraz obecność wskaźników antropogenicznych w diagramach pyłkowych od okresu subborealnego sugerują, że działalność człowieka, przejawiająca się wylesieniami, musiała skutkować ożywieniem procesów eolicznych. Drewno pozyskiwano na surowiec budowlany, ale także wykorzystywano je w metalurgii. Innym dowodem procesów holoceńskiej redepozycji wydmy w Szczepidle są ostańce deflacyjne spotykane w lesie sosnowym w kierunku północnym od stanowiska. Mają one charakter niewielkich kopców piaszczystych porośniętych roślinnością. Liczne przykłady tego rodzaju małych form akumulacyjnej działalności wiatru opisał Twardy (2008). Ich powstanie związane jest $\mathrm{z}$ selektywnym wywiewaniem i rozczłonkowywaniem pokrywy piaszczystej, którą pierwotnie porastała nierównomiernie roślinność. W efekcie tych procesów pozostają płaskie kulminacje porośnięte przez roślinność, którym ostateczny kształt nadają procesy stokowe. Opisywane procesy ustają, gdy na całej powierzchni pojawi się pokrywa roślinna (Klimaszewski 1981).

\section{Przemiany szaty roślinnej}

Badany obszar jest dość zróżnicowany pod względem potencjalnej roślinności naturalnej (Matuszkiewicz 1993). Z jednej strony tworzy go siedlisko środkowoeuropejskich grądów dębowo-grabowych (Galio silvatici-Carpinetum), z drugiej występują tutaj płaty siedlisk borów mieszanych dębowo-sosnowych (Pino-Quercetum) i środkowoeuropejskiego boru sosnowego (Leucobryo-Pinetum). Dno doliny Warty stanowi siedlisko łęgu jesionowo-olchowego (Circaeo-Alnetum). Dominującym gatunkiem drzew na całym obszarze jest sosna, w dalszej kolejności dąb, brzoza i olcha.

$\mathrm{Z}$ istniejących opracowań palinologicznych obejmujących badany teren o przemianach roślinnych informuje diagram wykonany dla osadów organogenicznych z rynny rozcinającej wysoczyznę w okolicy Konina, na północ od miasta (Borówko-Dłużakowa 1969). Spąg ponad 6-metrowego profilu wydatowany został na $11840 \pm 180$ BC (GRO 2024), co pozwoliło na rekonstrukcję roślinności od najstarszego dryasu aż po okres subatlantycki. Od spągu profilu dominowały Pinus $i$ Betula $\mathrm{z}$ domieszką Larix. Dodatkowym wskaźnikiem warunków tundrowych 


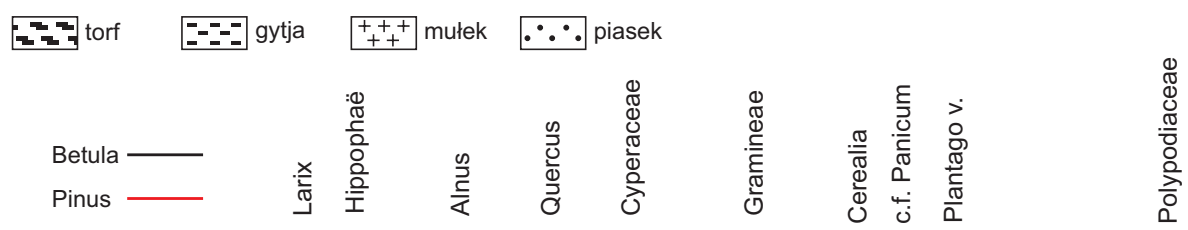

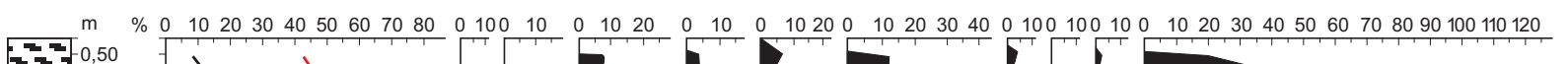

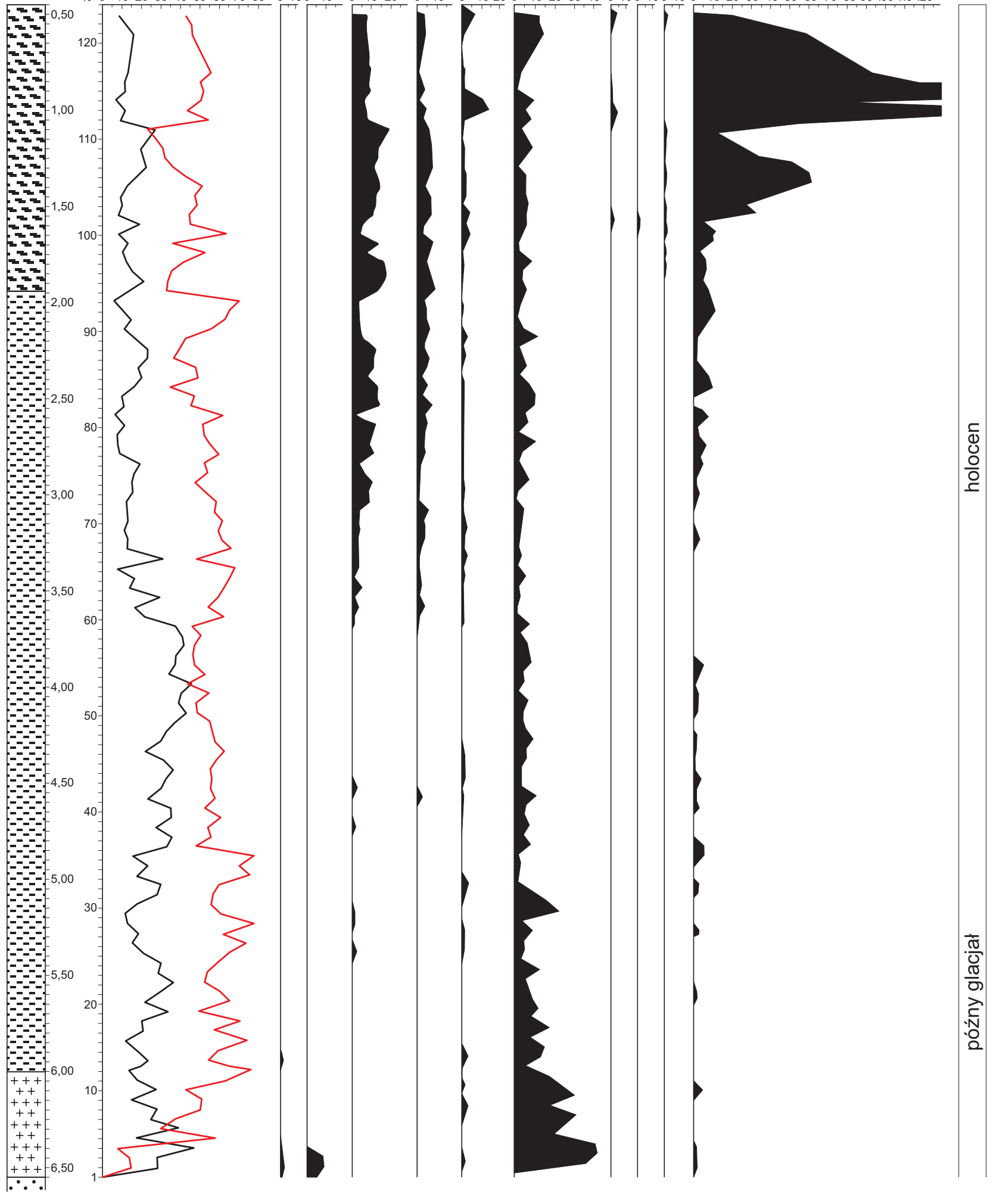

Ryc. 8. Przekształcenia roślinności w późnym glacjale i holocenie oraz wybrane wskaźniki synantropizacji środowiska w okolicy Konina opracowane na podstawie diagramu palinologicznego Borówko-Dłużakowej (1969)

Fig. 8. Transformation of vegetation in the Late Glacial and Holocene, and selected indicators of the synanthropisation of the environment in the Konin area prepared on the basis of Borówko-Dłużakowa's (1969) palynological diagram 
w późnym glacjale był rokitnik (Hippophaë rhamnoides L.). Największą kulminację brzozy i sosny odnotowano na początku okresu preborealnego, ponadto obserwuje się w tym czasie konsekwentny rozwój wiązu, olchy, dębu, lipy i, po raz pierwszy, leszczyny. W okresie atlantyckim w profilu palinologicznym odnotowana jest charakterystyczna kulminacja lipy i dębu. W tym czasie zaobserwowano również rozwój buka, grabu i świerka (Borówko-Dłużakowa 1969) (ryc. 8).

W okresie subborealnym obserwuje się w profilu przejście pomiędzy mieszanym lasem dębowym a ekspansją buka. Przy czym ten drugi proces w badanym profilu nie zaznacza się w sposób istotny. Notuje się w tym okresie spadek leszczyny, ale z kolei utrzymuje się wysoki udział sporomorf Populus, Ligustrum i Viburnum. Poza roślinami zielnymi, znaczącą rolę zaczynają odgrywać rośliny synantropijne: Centaurea cyanus, Cerealia, Humulus lupulus, cf. Panicum, Papaver, Plantago, Rumex, Urtica i Viscum album. Mogą być one dowodem aktywności człowieka polegającej na wycinaniu lasu i wprowa-

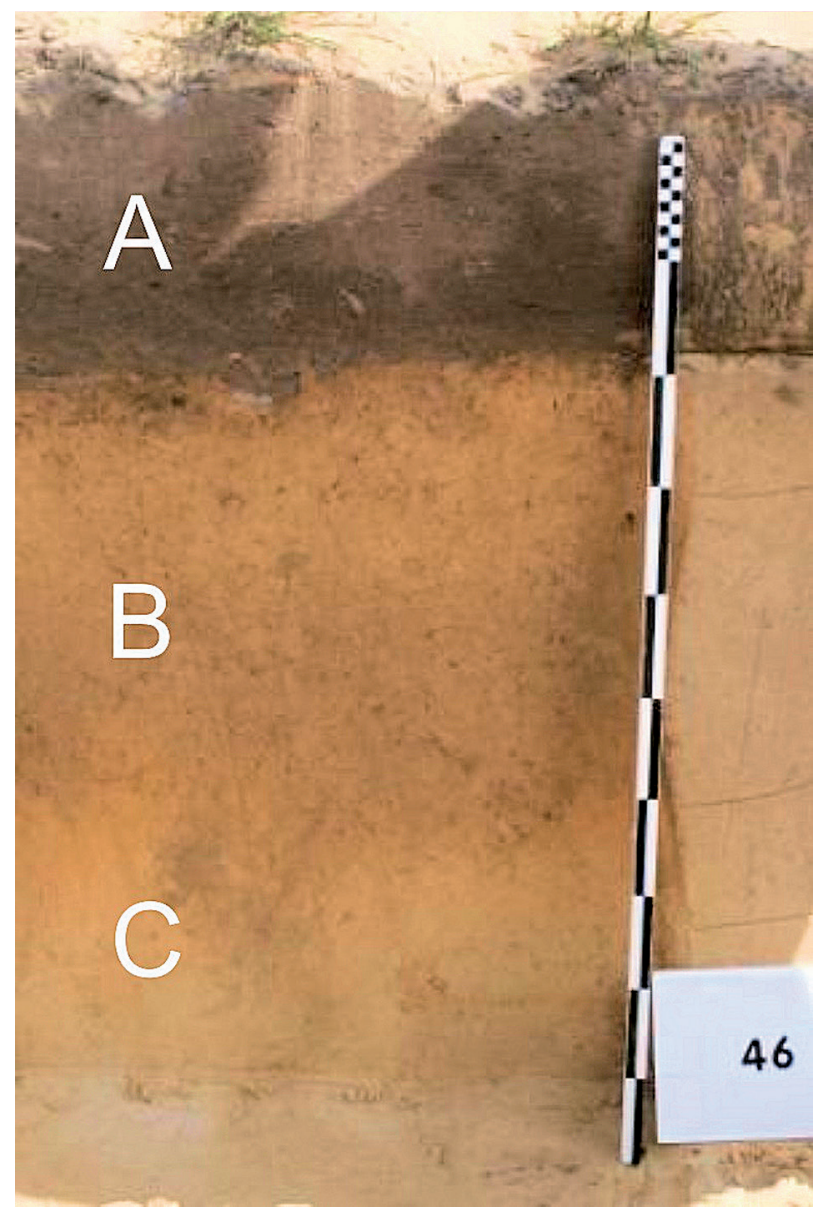

Ryc. 9. Stratygrafia pokryw eolicznych na stanowisku archeologicznym Szczepidło 17

A - warstwa próchnicza, B - poziom piasków eolicznych barwy od rdzawej do brązowej, C - poziom piasków eolicznych o barwie jasnobeżowej

Fig. 9. Stratigraphy of aeolian covers at the Szczepidło 17 archeological site

A - humus layer, B - level of aeolian sands rusty to brown in colour, $\mathrm{C}$ - level of light-beige aeolian sands dzeniu upraw. Dodatkowym wskaźnikiem antropopresji jest kulminacja sporomorf Polypodiaceae i wzrost procentowy traw i turzyc.

W okresie subatlantyckim wpływ człowieka się nasilał. W udziale sporomorf zaznacza się grab i buk. Wzrasta udział roślin uprawnych oraz traw i turzyc. Spośród roślin uprawnych wymienić można Triticum, Secale. Pierwsze ich ślady są czytelne w diagramie od okresu atlantyckiego. Poza nimi w diagramie stosunkowo często znajdowano proso (Panicum), które może być interpretowane jako uprawa, którą pierwszą stosowano na powierzchniach po wypalonym czy wykarczowanym lesie (ziarna prosa uprawowego wyraźnie różnią się od tych rosnących dziko). Często fakt ten datuje się na okres wczesnego lub środkowego brązu (Ralska-Jasiewiczowa 1966). Na podstawie omawianego diagramu można potwierdzić aktywność człowieka w badanym regionie od okresu subborealnego. Człowiek wykorzystywał zasoby leśne pradoliny i wysoczyzn na potrzeby budowy osad, ale także opału w metalurgii (kultura mogiłowa w Szczepidle), jednocześnie wprowadzał gatunki uprawowe. Wszystkie te działania skutkowały postępującymi wylesieniami.

\section{Litologia podłoża wydmowego i obiektów archeologicznych}

Budowa obszaru wydmowego na stanowisku archeologicznym jest dosyć jednorodna. Pod dwudziestocentymetrową warstwą próchniczą występuje również dwudziestocentymetrowa lub bardziej miąższa warstwa piasku eolicznego barwy od rdzawej do brązowej (ryc. 9). Zabarwienie tej warstwy powiązać można $\mathrm{z}$ procesem rdzawienia (poziom diagnostyczny sideric), który jest charakterystyczny dla gleb rdzawych. Pod tą warstwą występują już jednolite piaski eoliczne o zabarwieniu beżowym (skała macierzysta).

Wyniki analiz uziarnienia potwierdziły, że jest to osad piaszczysty. W przypadku próbki glebowej (1) był to utwór, który składa się w 99,5\% z piasku i 0,5\% pyłu. Na tę domieszkę wpływ ma zapewne materia organiczna, która znajduje się w warstwie humusowej. Próbka z osadów podłoża wydmy (2) w całości zbudowana jest z materiału piaszczystego. Parametry uziarnienia wskazują, że osad

Tabela 1. Podstawowe parametry uziarnienia obliczone metodą Folka, Warda (Racinowski i in. 2001) w programie GRADISTAT wersja 4.0 (Blott, Pye 2001)

Table 1. Basic grain-size parameters calculated using FolkWard's method (Racinowski et al. 2001) in the GRADISTAT program, version 4.0 (Blott, Pye 2001)

\begin{tabular}{lcc}
\hline \multicolumn{1}{c}{$\begin{array}{c}\text { Parametry } \\
\text { uziarnienia (phi) }\end{array}$} & $\begin{array}{c}\text { Próbka nr 1 } \\
\text { (glebowa) }\end{array}$ & $\begin{array}{c}\text { Próbka nr 2 } \\
\text { (podłoże wydmowe) }\end{array}$ \\
\hline Mediana & 2,34 & 2,38 \\
Odchylenie standardowe & 0,51 & 0,39 \\
Skośność & 0,10 & $-0,007$ \\
Kurtoza & 0,99 & 0,99 \\
\hline
\end{tabular}




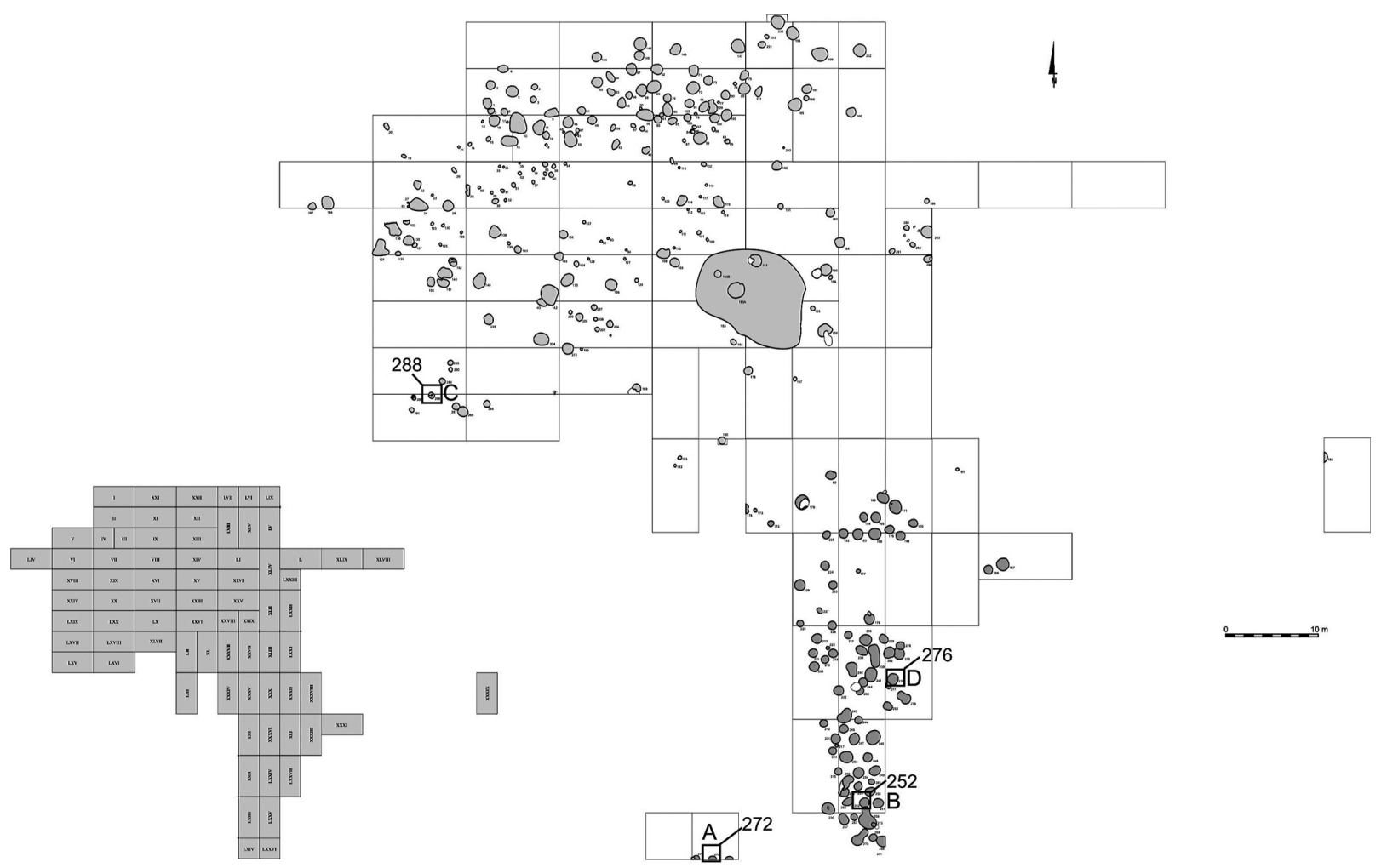

Ryc. 10. Zasięg wykopów archeologicznych oraz rozmieszczenie obiektów na stanowisku w Szczepidle (za Makarowicz, Garbacz-Klempka 2014)

A - obiekt 252, B - obiekt 272, C - obiekt 288, D - obiekt 276

Fig. 10. Range of archeological pits and the arrangement of objects at the Szczepidło site (after Makarowicz, Garbacz-Klempka 2014) A - object 252, B - object 272, C - object 288, D - object 276
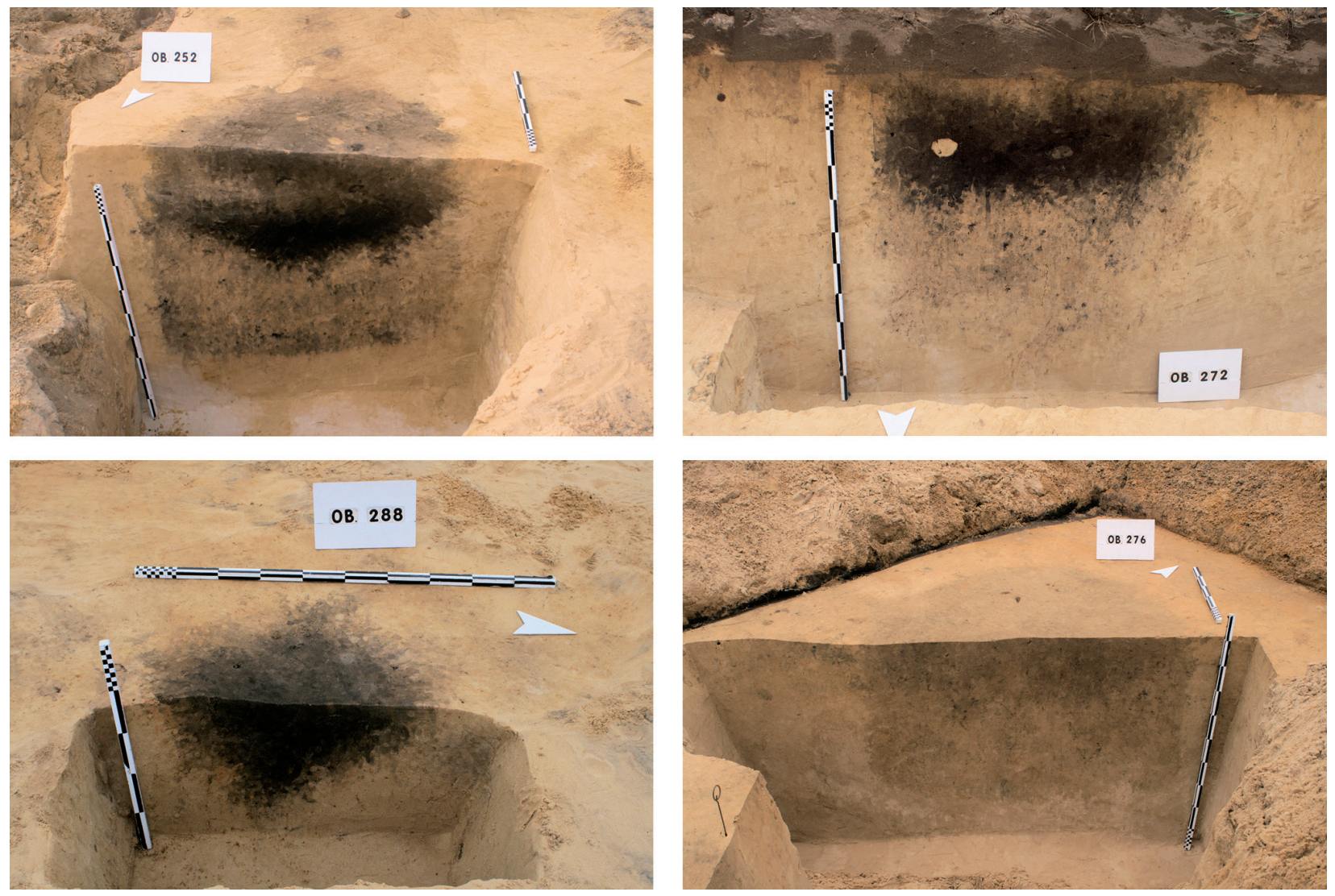

Ryc. 11. Zróżnicowanie stratygraficzne obiektów na stanowisku archeologicznym w Szczepidle (fot. P. Makarowicz)

Fig. 11. Stratigraphic differences among objects at the Szczepidło archeological site (Photo by P. Makarowicz) 
występujący na powierzchni stanowiska archeologicznego to osad wydmowy, dobrze wysortowany (tab. 1). Niewielkie ujemne wartości wskaźnika skośności mogą wskazywać, że obszar wydmowy mógł być selektywnie rozwiewany, tj. pozbawiany frakcji drobniejszych, ale generalnie jest to rozkład symetryczny. Wskaźnik kurtozy świadczy o wysokiej monofrakcyjności osadu, który powstawał w jednorodnych warunkach środowiska sedymentacyjnego.

Jednym z dowodów obecności kultury mogiłowej na stanowisku archeologicznym w Szczepidle są liczne obiekty archeologiczne (ryc. 10, 11). Występują one praktycznie we wszystkich częściach stanowiska, z tym, że największa ich koncentracja odnotowana została w południowej jego części. Do tej pory zarejestrowano 291 różnych obiektów. Nie są to formy głębokie. Głębokość obiektów mieści się w przedziale od 20-30 cm do około $1 \mathrm{~m}$. Charakteryzują się one wyjątkowo zróżnicowaną stratygrafią, co pozwala na stwierdzenie, że różniły się pod względem wykorzystania funkcjonalnego. Do tej pory udało się rozpoznać jamy gospodarcze-piwniczki, jamy śmietnikowe, dołki posłupowe oraz warsztat metalurgiczny. Stratygrafia paleniska pozwala na wnioskowanie na temat wieloetapowego i zróżnicowanego pod względem intensywności wykorzystania opisywanych obiektów. Wypełniska charakteryzują się różnym stopniem nasycenia próchnicą. Wynika to $\mathrm{z}$ pierwotnego zróżnicowania zawartości materiału organicznego, ale także ze stopnia intensywności jego rozkładu w wyniku procesów podepozycyjnych i glebotwórczych. Poprzez zróżnicowaną zawartość próchnicy odczytać można warstwowanie obiektów - fazy intensywnego użytkowania. Wykorzystanie obiektów mogło mieć miejsce tuż po ich powstaniu (obiekt 267). W przypadku niektórych obiektów obserwuje się drugą fazę użytkowania, kiedy obiekty były już niekiedy w połowie wypełnione warstwami kulturowymi i materiałem naturalnym, który bardzo szybko je degradował, gdyż formy te wykopane zostały w eolicznym podłożu, niezwykle wrażliwym na działalność wiatru (obiekty 252 i 272). Na stanowisku występują również obiekty, które mogą być zapisem jednokrotnego ich wykorzystywania, bez czytelnego warstwowania (obiekt 276).

Wszystkie próbki pobrane $\mathrm{z}$ obiektów reprezentują piasek średni lub drobny, mieszczący się najczęściej we frakcjach 1,6-2,0 phi (tab. 2, ryc. 12). Sa to osady dobrze lub umiarkowanie dobrze wysortowane, co znaczy, że powstawały w stosunkowo jednorodnych warunkach litodynamicznych i reprezentują osad monofrakcyjny. Rozkłady uziarnienia charakteryzują się symetrycznością lub niewielką skośnością ujemną, co może świadczyć o selektywnym wywiewaniu osadu, ale skala tego procesu nie była duża. Spłaszczenie rozkładu uziarnienia (kurtoza) potwierdza jednorodność warunków dynamicznych w środowisku sedymentacyjnym, gdyż rozkłady są albo mezokurtyczne, albo leptokurtyczne. Piaski średnie stanowią 48-57\% osadu, drobne piaski od 30 do $46 \%$, a bardzo drobny piasek od 1 do 2\% Uzupełnieniem składu granulometrycznego osadów są pyły, których zawartość wynosi również $1-2 \%$.

Ze względu na nieduże zróżnicowanie litologiczne całego stanowiska archeologicznego zbudowanego z osadów wydmowych, również zmienność cech litologicznych obiektów jest niewielka. Bardziej szczegółowej analizie poddano 2 obiekty: obiekt 268 obejmujący 3 warstwy mechaniczne, z których pobrano 9 próbek oraz obiekt numer 236, z którego pobrano 13 próbek.

Obiekt 268 jest obiektem piaszczystym, w części stropowej wzbogaconym w większe udziały frakcji pylastej (ryc. 12). Zarówno zawartość strat prażenia, jak węglanów wapnia maleje ku spągowi. Udział $\mathrm{CaCO}_{3}$ w całym profilu jest śladowy. Niskie wartości obu składników

Tabela 2. Podstawowe wskaźniki uziarnienia, struktura uziarnienia osadów w procentach oraz udziały procentowe strat prażenia i zawartości węglanów wapnia w obiektach archeologicznych

Table 2. Basic granulation indices, granulation structure of deposits in per cent, loss-on-ignition percentages, and calcium carbonate content in the archeological objects

\begin{tabular}{|c|c|c|c|c|c|c|c|c|c|c|}
\hline \multirow[t]{2}{*}{$\mathrm{Nr}$ próbki } & \multirow[t]{2}{*}{ Obiekt } & \multirow[t]{2}{*}{ Warstwa } & Mediana & Wysortowanie & Skośność & Kurtoza & Piasek & Pył & $\begin{array}{c}\text { Materia } \\
\text { organiczna }\end{array}$ & $\mathrm{CaCO}_{3}$ \\
\hline & & & \multicolumn{4}{|c|}{ [phi] } & \multicolumn{4}{|c|}{$[\%]$} \\
\hline $1588 / \mathrm{A}$ & 268 & I-III & 1,972 & 0,573 & 0,033 & 1,083 & 97,68 & 2,32 & 1,15 & 0,23 \\
\hline 1588/B & 268 & I-III & 1,890 & 0,519 & 0,021 & 0,998 & 99,31 & 0,69 & 0,53 & 0,20 \\
\hline $1588 / \mathrm{C}$ & 268 & I-III & 1,886 & 0,931 & 0,265 & 1,955 & 94,16 & 5,84 & 0,61 & 0,16 \\
\hline 1588/D & 268 & I-III & 1,603 & 0,710 & $-0,019$ & 1,279 & 96,43 & 3,57 & 0,56 & 0,13 \\
\hline $1588 / \mathrm{E}$ & 268 & I-III & 1,942 & 0,752 & 0,147 & 1,495 & 95,33 & 4,67 & 0,45 & 0,12 \\
\hline $1588 / \mathrm{F}$ & 268 & I-III & 1,994 & 0,623 & 0,072 & 1,159 & 96,68 & 3,32 & 0,38 & 0,12 \\
\hline $1588 / \mathrm{G}$ & 268 & I-III & 1,807 & 0,570 & $-0,040$ & 1,010 & 99,94 & 0,06 & 0,35 & 0,06 \\
\hline 1588/H & 268 & I-III & 1,766 & 0,588 & $-0,064$ & 1,025 & 99,90 & 0,10 & 0,38 & 0,18 \\
\hline 1588/I & 268 & I-III & 1,943 & 0,551 & 0,016 & 1,053 & 99,03 & 0,97 & 0,31 & 0,12 \\
\hline 1589/A & 276 & I-III & 1,953 & 0,552 & 0,021 & 1,073 & 98,63 & 1,37 & 0,57 & 0,16 \\
\hline 1589/B & 276 & I-III & 1,886 & 0,602 & $-0,002$ & 1,088 & 98,48 & 1,52 & 0,39 & 0,23 \\
\hline 1590 & 272 & I & 1,722 & 0,556 & $-0,059$ & 1,011 & 99,97 & 0,03 & 1,66 & 0,24 \\
\hline 1597 & 288 & III & 1,965 & 0,478 & $-0,030$ & 1,039 & 99,92 & 0,08 & 1,20 & 0,26 \\
\hline
\end{tabular}




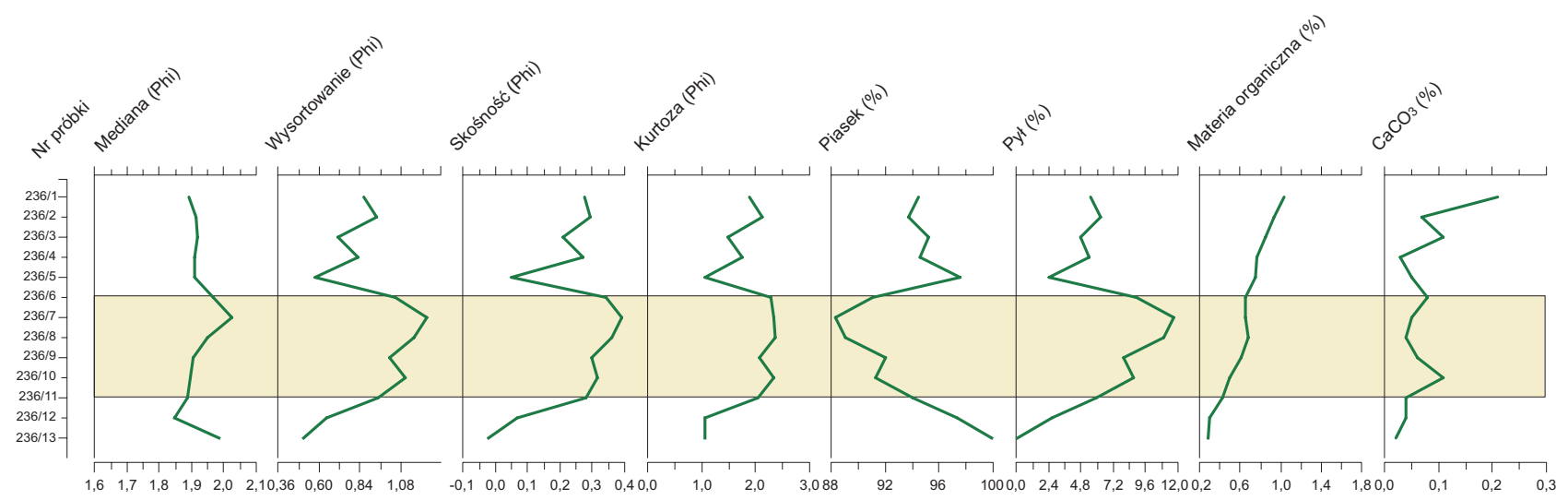

Ryc. 12. Podstawowe wskaźniki uziarnienia, struktura uziarnienia osadów w procentach oraz udziały procentowe strat prażenia i zawartości węglanów wapnia w obiektach archeologicznych z profilu obiektu 236 z wykopu LXXXIV

Fig. 12. Basic granulation indices, granulation structure of deposits in per cent, loss-on-ignition percentages, and calcium carbonate content of a profile of object 236 from pit no. LXXXIV

świadczą, że analizowany osad występuje w środowisku kwaśnym, agresywnym, rozkładającym próchnicę oraz rozpuszczającym węglan wapnia. Niewątpliwie czynnikiem sprzyjającym tym zjawiskom jest występujący wokół stanowiska drzewostan sosnowy, który uruchomił procesy rdzawienia i bielicowania gleb. Obserwowana jednakowa tendencja w spadku zawartości materii organicznej i $\mathrm{CaCO}_{3}$ od stropu do spągu obiektu świadczy o jednofazowości użytkowania obiektu.

W drugim przypadku w obiekcie 236 zaobserwować można dwufazowość w użytkowaniu formy. Po wykopaniu obiektu zaznacza się w spągowej warstwie akumulacja piaszczysta związana $z$ naturalnymi procesami obrywania, osypywania osadu ze ścian obiektu (próbki 12 i 13). W drugim etapie użytkowania obiektu powstało wypełnisko piaszczyste, ale z dużym udziałem pyłów (do 10-12\%), ze stratami prażenia około $0,5 \%$ i nieco zaznaczającą się, ale śladową zawartością $\mathrm{CaCO}_{3}$ (próby od 6 do11). Trzecią fazę użytkowania obiektu charakteryzuje wypełnisko zbudowane głównie z piasku, ale z mniejszym udziałem mułków oraz największym wskaźnikiem strat prażenia wynoszącym około $1 \%$ i malejącą ku spągowi zawartością węglanu wapnia. Taki sposób wykorzystania obiektu potwierdzają również wyniki badań składu geochemicznego przedstawione w dalszej części opracowania (próbki od 1 do 5).

Największe wartości strat prażenia i węglanu wapnia spośród wszystkich badanych próbek odnotowano W obiekcie 272 (I WM, nr próby 1590) i obiekcie 288 (III WM, nr próby 1597), są to wartości 1,6 i 1,4\% w przypadku strat prażenia, czyli w skali bezwzględnej niewysokie i jeszcze niższe w przypadku $\mathrm{CaCO}_{3}$. Wyniki te potwierdzają wniosek o silnej infiltracji i przemywaniu gleby stanowiska ze składników pokarmowych.

\section{Geochemiczne cechy obiektów archeologicznych}

Ze względu na niedogodne na stanowisku archeologicznym warunki do zachowania zapisu składu geochemicznego skutków działalności człowieka analizie poddano zawartość jednego obiektu oznaczonego numerem 236 (ryc. 13). Jak już zauważono wcześniej, ze względu na specyficzne warunki środowiskowe stanowiska archeologicznego zaznaczające się dominacją wydmowego materiału piaszczystego, niewielkim udziałem frakcji pylastej oraz materii organicznej (próchnicy), która nawet jeżeli

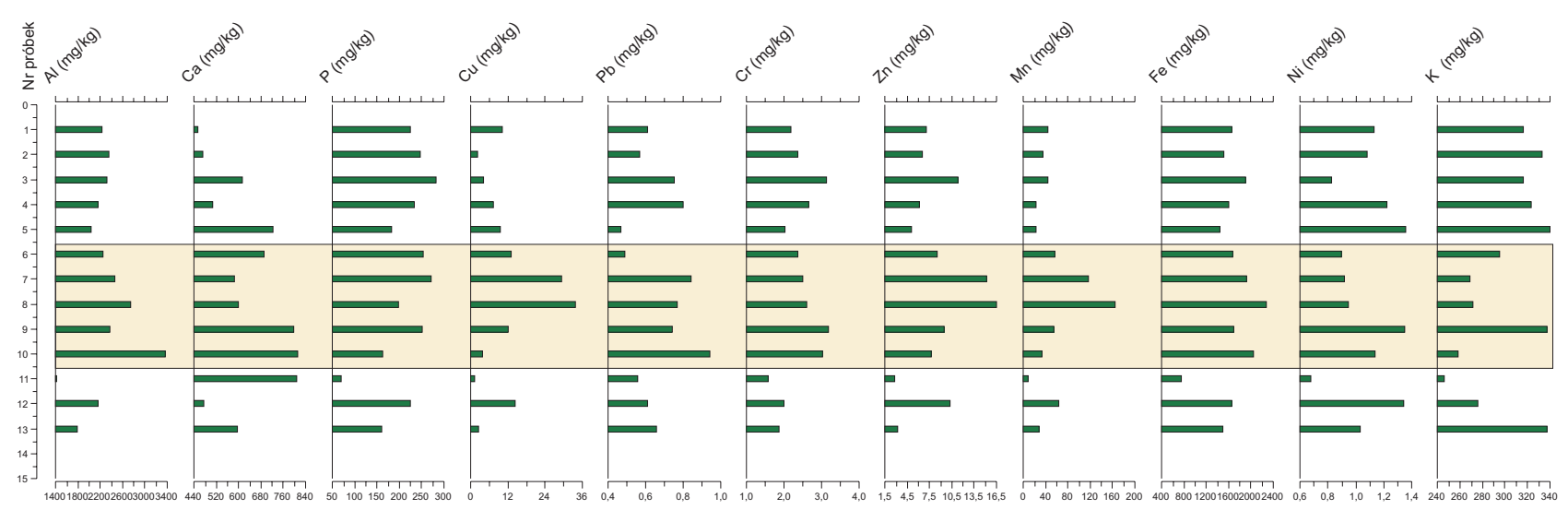

Ryc. 13. Skład geochemiczny pierwiastków głównych i śladowych wykonanych dla profilu pobranego z obiektu 236 z wykopu LXXXIV

Fig. 13. Representative and trace elements in the geochemical composition of a profile of object 236 from pit no. LXXXIV 
pierwotnie występowała, to szybko ulegała rozkładowi, możliwości zapisu geochemicznego są ograniczone. Bardzo niewiele jest osadów, które mogłyby stanowić kompleks sorpcyjny dla procesów chemicznych zachodzących na stanowisku. W rezultacie otrzymane wartości poszczególnych składników geochemicznych są generalnie niskie.

Minimalna zawartość fosforu ogółem w poziomach antropogenicznych została określona przez Gebhardta (1992) na $200 \mathrm{mg} \mathrm{kg}^{-1}$, natomiast w Systematyce Gleb Polski z 1989 r. wartość graniczna wpływu antropogenicznego wynosi $250 \mathrm{mg} \mathrm{kg}^{-1}$. Jednak badania prowadzone na stanowiskach archeologicznych dowiodły, że granice te mogą być różne i najlepiej jest określać tło geochemiczne zawartości tego pierwiastka w glebach i osadach znajdujących się w bezpośrednim sąsiedztwie badanych stanowisk archeologicznych, których nie obejmowała dawna działalność człowieka (Bednarek 2007). Maksymalne wartości fosforu ogólnego w profilu obiektu 236 mieszczą się w przedziale $270-280 \mathrm{mg} \mathrm{kg}^{-1}$ (ryc. 13). Przekraczają zatem wartości graniczne i wskazują na antropogenizację badanego obszaru. Nie występują one równomiernie w profilu. Od stropu (próbki 1-5) i w części środkowej profilu (próbki 6-10) notuje się większą zawartość fosforu ogólnego. Najniższe wartości zaobserwować można w spągu. Podobna tendencja charakteryzuje rozkład większości oznaczonych pierwiastków. Wskazuje ona, co zaznaczono wcześniej, na dwuetapowość wykorzystywania obiektu.

Innym dowodem antropogenizacji obszaru, ustalonym na podstawie badań obiektu 236, jest specyficzna zależność pomiędzy śladowymi pierwiastkami $\mathrm{Cu}: \mathrm{Pb}: \mathrm{Zn}$. Według badań eksperymentalnych Weng i in. (2003) zastosowanych przez Zgłobickiego (2008) można wyróżnić

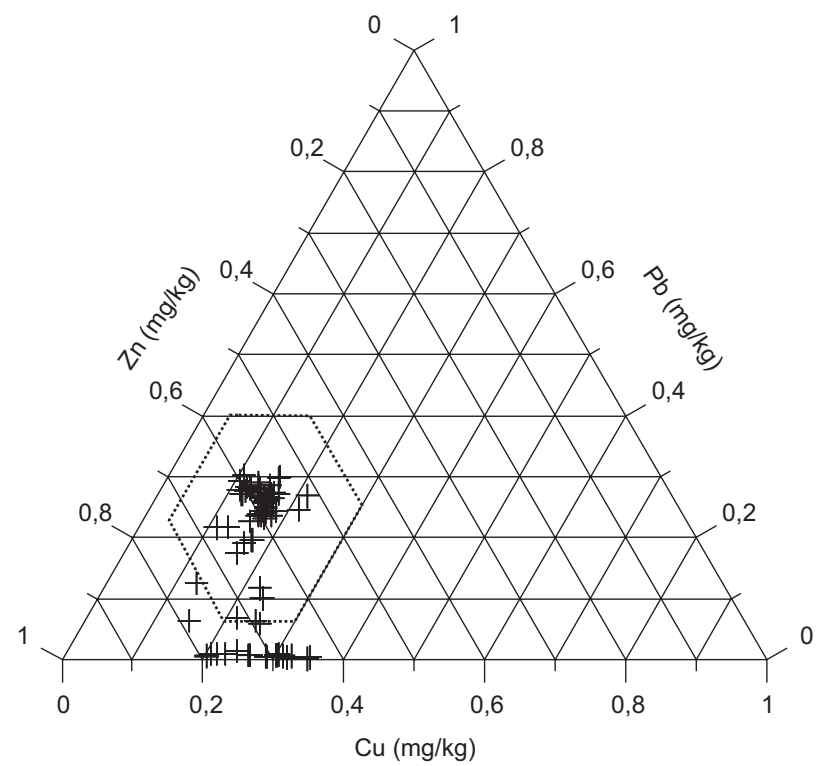

Ryc. 14. Zależności pomiędzy pierwiastkami $\mathrm{Cu}, \mathrm{Pb}$ i $\mathrm{Zn}$. Wewnątrz obszaru zaznaczonego linią przerywaną wartości uznawane za naturalne (Weng i in. 2003)

Fig. 14. Relationships between the elements $\mathrm{Cu}, \mathrm{Pb}$ and $\mathrm{Zn}$. Inside the area marked by a dashed line, values considered natural (Weng et al. 2003) obszary na wykresie, gdzie ta zależność jest dowodem antropogenizacji (ryc. 14). Analiza ryciny 14 pozwala wnioskować, że większość wartości znajduje się poza strefą uznawaną za wynikającą z procesów naturalnych, pomimo faktu, że w kategoriach bezwzględnych wartości $\mathrm{Cu}, \mathrm{Pb}, \mathrm{Zn}$ i innych pierwiastków w badanym profilu nie są wysokie. Warto w tym miejscu wspomnieć, że jeden z obiektów na stanowisku zaklasyfikowano jako warsztat metalurgiczny, w którym znaleziono produkty i półprodukty brązowe. Pod pojęciem brązu antycznego uważano stop miedzi z cynkiem.

Wartości pierwiastków i pionowa zmienność glinu, wapnia, manganu, żelaza czy potasu związane są bardziej z właściwościami skały macierzystej, czyli osadów piaszczystych, oraz procesami glebotwórczymi niż działalnością antropogeniczną (Lis, Pasieczna 1995). Występują one $\mathrm{w}$ różnorodnych związkach, tlenkach i wodorotlenkach, charakteryzujących się dużą mobilnością. W środowisku kwaśnym cechują się sporą rozpuszczalnością, stąd ich podwyższone koncentracje na obszarach z zaznaczającymi się procesami rdzawienia lub bielicowania, będą tam związane przede wszystkim z poziomem iluwialnym.

\section{Naturalne i antropogeniczne przekształcenia stanowiska archeologicznego i jego najbliższego otoczenia}

Główne rysy rzeźby południowej części Odcinka Konińskiego Pradoliny Warty mają genezę związaną z procesami naturalnymi, głównie z cyklem glacjalnym ostatniego zlodowacenia - północnopolskiego, kiedy to ukształtowały się polodowcowe formy terenu, oraz cyklem postglacjalnym (późnoglacjalnym i holoceńskim), w którym zaznaczały się inne niż poprzednio procesy morfotwórcze na obszarze pradoliny. Należały do nich procesy erozji i akumulacji rzecznej, działalność eoliczna oraz procesy torfotwórcze. Relacje czasowe pomiędzy nimi oraz skalą tych procesów wskazują, że ich natężenie warunkowane było przede wszystkim poziomem wody na obszarze pradoliny. Drugim czynnikiem, wpływającym szczególnie na dynamikę procesów eolicznych, był stopień zalesienia pradoliny, który to od okresu późnego glacjału aż do czasów współczesnych znacznie się zmieniał. Na początku okresu poźnoglacjalnego panowały warunki tundrowe, o czym świadczy obecność rokitnika w profilu palinologicznym (Borówko-Dłużakowa 1969). Pojawiają się pyłki sosny, brzozy i modrzewia. Okresy zimne i suche późnego glacjału oraz brak zwartej pokrywy roślinnej sprzyjały procesom eolicznym. Obszarami źródłowymi procesów eolicznych były głównie osady wodnolodowcowe zdeponowane na powierzchniach teras i dna pradoliny. Większość badań wskazuje na młodszy dryas jako okres najintensywniejszego tworzenia się największych i najbardziej wyraźnych form wydmowych (Nowaczyk 1986).

Największa skala transformacji rzeźby na stanowisku archeologicznym oraz w jego otoczeniu wiąże się rów- 
nież z procesami eolicznymi. Człowiek, wkraczając na obszar pradoliny w okresie subborealnym, zastał ukształtowane formy wydmowe wyniesione ponad dno doliny i porośnięte zapewne lasem. Datowania radiowęglowe z obiektów na stanowisku archeologicznym mieszczą się $\mathrm{w}$ przedziale czasowym od $3260 \pm 50 \mathrm{BP}(1610-1490$ cal BC) (Ki 5591) do $2870 \pm 60$ BP (1130-970 cal BC) (Ki 8034). Przedział ten obejmuje fazę notowanej w wielu dolinach rzecznych Polski stabilizacji warunków hydrologicznych, które wynikały z osuszenia i ochłodzenia klimatu (Ralska-Jasiewiczowa, Starkel 1988, 2011). Był to zapewne czynnik, który sprzyjał osadnictwu. Po niej obserwuje się względnie dłuższy okres powolnego ocieplenia i wzrostu wilgotności klimatu w dolinach rzecznych, z maksimum pomiędzy 2900 a 2800 BP, co z kolei mogło się przyczynić do podjęcia decyzji o przeniesieniu osadnictwa (najmłodszy obiekt datowany na stanowisku jest na $2870 \pm 60 \mathrm{BP}$ ).

Od okresu subborealnego, jak wynika z profilu palinologicznego, w coraz większym stopniu w przekształceniach szaty roślinnej zaznacza się działalność człowieka (Borówko-Dłużakowa 1969). Na skutek karczowania lub wypalania lasów przyspieszony został przede wszystkim spływ powierzchniowy wód opadowych. W dolinie Warty mogły się odkładać mady związane z przepływami pozakorytowymi. Od tego czasu w pradolinie warunki hydrologiczne w coraz większym stopniu uzależnione są również od czynnika antropogenicznego, który nakłada się na naturalne procesy obiegu wody w zlewni.

O holoceńskich procesach eolicznych na obecnym etapie badań można się jedynie wypowiadać na podstawie rozpoznania archeologicznego wydmy w Machniaczu. W formie tej, pod nadkładem osadów eolicznych o miąższości 1,5 m, natrafiono na kilka poziomów gleb kopalnych. Niestety nie są one wydatowane, trudno więc rozstrzygnąć, czy dotyczą późnoglacjalnego etapu powstawania czy już holoceńskiego etapu redepozycji osadów eolicznych. Jednak skala zasiedlenia wydmy w Szczepidle oraz obecność wskaźników antropogenicznych w diagramach pyłkowych od okresu subborealnego sugerują, że działalność człowieka przejawiająca się wylesieniami, musiała skutkować ożywieniem procesów eolicznych. Drewno pozyskiwano na surowiec budowlany, ale także wykorzystywano je w metalurgii. Z bliższych geograficznie terenów udokumentowano znaczne pod względem skali i synchroniczne przekształcenia morfologii i struktury dużej wydmy w Kraskach (Krajewski 1977), datowane na $3050 \pm 130$ lat BP, oraz - na mniejszą już skalę - wydmy na stanowisku Grabek (Marosik 2002), datowane na $2970 \pm 50$ lat BP, i wydmy na stanowisku Rąbień (Marosik 2011), datowane na $3110 \pm 130$ lat BP. Okres wzmożonej działalności wiatru, procesów stokowych i rzecznych został ujęty w fazę II antropogenicznej transformacji rzeźby centralnej części Polski środkowej (Twardy 2008, 2011). Odpowiada on chronologicznie dość dokładnie okresowi zasiedlenia stanowiska w Szczepidle (st. 17), choć na obszarze regionu łódzkiego tej jednostki kulturowej nie wyróżnia się.
Równolegle $\mathrm{z}$ procesami osadniczymi w pradolinie funkcjonowała rzeka Warta. Kształt i rozmiary jej koryta warunkowane były reżimem hydrologicznym. Ślady zapisu przebiegu dawnych koryt rzecznych czytelne są w postaci starorzeczy wypełnionych osadami mineralno-organicznymi. Znajdują się one głównie w środkowej i północnej części pradoliny, natomiast w południowej dominowały procesy eoliczne i torfotwórcze. Te ostatnie zachodziły w obniżeniach teras, najczęściej w obrębie niecek deflacyjnych.

Do pośrednich skutków działalności człowieka, oprócz procesów eolicznych, na badanym obszarze zaliczyć można procesy stokowe. Pokrywy stokowe powstawały na południowej krawędzi pradoliny, głównie w wyniku spłukiwania, i zapisane są w postaci osadów deluwialnych. W ujściowych odcinkach dolinek erozyjno-denudacyjnych uchodzących do pradoliny zachowały się niekiedy osady proluwialne. Jednak na większą skalę proces powstawania pokryw stokowych należy wiązać już z czasami, kiedy powszechna była orka na obszarach wysoczyznowych.

Najbardziej czytelnym przejawem działalności człowieka na stanowisku są formy bezpośredniej jego działalności - obiekty archeologiczne. Prawdopodobnie usytuowanie stanowiska w obrębie niecki deflacyjnej, ograniczyło negatywne skutki wynikające $\mathrm{z}$ tak dużego stopnia ingerencji człowieka w powierzchniową pokrywę eoliczną (na stanowisku odkryto do tej pory około 280 obiektów). Osłonięcie terenu stanowiska od strony zachodniej przez porośniętą wydmę w Machniaczu, a z pozostałych stron przez wydmę w Szczepidle o parabolicznym kształcie dodatkowo chroniło stanowisko przed procesami deflacji. Wzajemne relacje przestrzenne obiektów archeologicznych dowodzą, że formy te są wielofazowe, nie powstawały więc na całej przestrzeni stanowiska równocześnie. Można zatem wnioskować, że presja człowieka na środowisko również rozkładała się w czasie.

\section{Wnioski}

Najważniejsze wnioski dotyczą rozwoju paleogeograficznego analizowanego obszaru w późnym glacjale i holocenie oraz wzajemnych relacji osady kultury mogiłowej z otaczającym ją środowiskiem przyrodniczym, szczególnie eolicznym i fluwialnym.

1. Główne rysy rzeźby obszaru, na którym znajduje się stanowisko archeologiczne w Szczepidle, ukształtowane zostały w fazie leszczyńskiej i poznańskiej zlodowacenia północnopolskiego. Z fazą poznańską związane jest też uformowanie Pradoliny Warty.

2. Z suchymi i zimnymi okresami późnego glacjału, najpewniej z młodszym dryasem, powiązać można genezę wydm parabolicznych w Machniaczu i Szczepidle. Ukształtowane one zostały przez wiatry wiejące z sektorów zachodnich, z materiału wodnolodowcowego wywiewanego z pradoliny. 
3. Osadnictwo kultury mogiłowej zajęło obszar niecki deflacyjnej osłoniętej od strony zachodniej wydmą w Machniaczu, a z pozostałych stron stokami wydmy w Szczepidle.

4. Ulokowaniu osadnictwa kultury mogiłowej w pradolinie sprzyjały warunki klimatyczne okresu subborealnego, które określane są jako suche i chłodne.

5. Działalność człowieka przekształciła rzeźbę stanowiska archeologicznego, czyli niecki deflacyjnej. Powstały obiekty archeologiczne, które są pozostałościami działalności osadniczej i gospodarczej (metalurgicznej) zachodzącej na tych samych przestrzeniach stanowiska wielokrotnie.

6. Innym dowodem aktywności człowieka w rejonie stanowiska archeologicznego są palinologiczne wskaźniki synantropizacji środowiska, wskazujące na gatunki wprowadzane przez człowieka, ale też pośrednio na wylesienia (pojawiają się powierzchnie otwarte pola).

7. Od okresu subborealnego można obserwować nakładanie się wpływów antropogenicznych i naturalnych - klimatycznych - na kształtowanie reżimu hydrologicznego w dolinie Warty, co świadczy o coraz większej częstotliwości powodzi i akumulacji mad. Ten czynnik w konsekwencji mógł się przyczynić do opuszczenia osady około 2800 BP (okres wilgotnych warunków w dolinie).

\section{Podziękowanie}

Autorzy składają podziękowanie dwóm anonimowym recenzentom za cenne uwagi i komentarze do wcześniejszej wersji tego artykułu.

Praca finansowana ze środków budżetowych na naukę w latach 2010-2013, w ramach projektu badawczego N N109 054039

\section{Literatura}

Bednarek R., Markiewicz M., 2007. Zawartość fosforu w glebach jako wskaźnik dawnej działalności człowieka na wczesnośredniowiecznych grodziskach w Pokrzydowie i Gronowie (Pojezierze Chełmińsko-Dobrzyńskie). W: E. Smolska, P. Szwarczewski (red.), Zapis działalności człowieka w środowisku przyrodniczym. T. III. Wydawnictwo SWPR, Warszawa: 7-14.

Blott S.J., Pye K., 2001. Gradistat: A grain size distribution and statistics package for the analysis of unconsolidated sediments. Earth Surface Processes and Landforms 26: 1237-1248.

Borówka R.K., 1980. Współczesne procesy transportu i sedymentacji piasków eolicznych oraz ich uwarunkowania i skutki na obszarze wydm nadmorskich. PTPN, Prace Komisji Geograficzno-Geologicznej: $1-126$.

Borówko-Dłużakowa Z., 1969. Palynological investigations of Late Glacial and Holocene deposits at Konin. Geographia Polonica 7: 267-281.

Gebhardt H., 1982. Phosphatkartierung und bodenkundliche Geländeuntersuchungen zur Eingrenzug historischer Siedlungs- und Wirtschaftsflächen der Geestinsel Flögeln, Kreis Cuxhaven. Verlag August Lax Hildesheim.

Gedl M., 1989. Kultura przedłużycka. W: J. Kmieciński (red.), Pradzieje ziem polskich. T. I. Od paleolitu do środkowego okresu lateńskiego.
Cz. 2. Epoka brazu i początki epoki żelaza. Wydawnictwo Naukowe PWN, Warszawa-Łódź: 467-475.

Klimaszewski M., 1981. Geomorfologia. PWN, Warszawa.

Kłysz P., 1981. Morfogeneza zespołu form marginalnych między Koninem, Kołem a Turkiem. Wydawnictwo Naukowe UAM, Poznań.

Kondracki J., 1998. Geografia fizyczna Polski. PWN, Warszawa.

Kostrzewski J., 1953. Wytwórczość metalurgiczna w Polsce od neolitu do wczesnego okresu żelaza. Przegląd Archeologiczny 9: 177-213.

Kozacki L., 1972. Analiza i ocena środowiska geograficznego powiatu konińskiego dla potrzeb prognozowania jego zmian. PTPN, Prace Komisji Geograficzno-Geologicznej 6(3).

Kozacki L., Macias A., Markuszewska I., Rosik W. 2004. Komentarz do mapy sozologicznej w skali 1: 50 000. Arkusz N-34-133-B Konin. Główny Geodeta Kraju, GUGiK.

Kozarski S., Tobolski K., 1968. Holoceńskie przeobrażenia wydm śródlądowych w Wielkopolsce w świetle badań geomorfologicznych i palynologicznych. Folia Quaternaria 29: 127-134.

Krajewski K., 1977. Późnoplejstoceńskie i holoceńskie procesy wydmotwórcze w Pradolinie Warszawsko-Berlińskiej w widłach Warty i Neru. Acta Geogr. Lodz. 39: 1-87.

Krygowski B. 1961. Geografia fizyczna Niziny Wielkopolskiej. Cz. 1. Geomorfologia PWN, Poznań.

Lis J., Pasieczna A., 1995. Atlas geochemiczny Polski, 1:2 500000. PIG, Warszawa.

Makarowicz P., 2007. Osada metalurgów ludności kultury mogiłowej w Szczepidle, pow. koniński, gm. Krzymów, woj. wielkopolskie, stanowisko 17. Maszynopis dla KOBIDZ-u, Poznań.

Makarowicz P., Garbacz-Klempka A., 2014. Osada metalurgów w Szczepidle nad środkową Wartą. Z badań nad wytwórczością z brązu w II tys. BC, Fontes Praehistorici Posnanienses 50(2) (w druku).

Mańkowska A. 1974. Mapa geologiczna 1:200 000 Konin A 37. PIG, Warszawa.

Marks L., Ber A., Gogołek W., 2006. Mapa Geologiczna Polski, 1:500 000. Ministerstwo Środowiska - Państwowy Instytut Geologiczny, Warszawa.

Marosik P., 2002. Ukształtowanie terenu i warunki geologiczne na stanowisku archeologicznym nr $11 \mathrm{w}$ Grabku oraz na obszarze przyległym w dnie doliny Krasówki. W: R. Grygiel (red.), Badania archeologiczne na terenie odkrywki „Szczerców” Kopalni Węgla Brunatnego „Bełchatów” S.A. T. II. Fund. Bad. Archeolog. im. K. Jażdżewskiego, Fund. UAM, Łódź: 9-23.

Marosik P., 2011. Wydma i torfowisko „Rąbień” w Aleksandrowie Łódzkim w świetle badań geomorfologicznych. W: E. Niesiołowska-Śreniowska, D.K. Płaza, P. Marosik, Z. Balwierz (red.), Obozowiska ze starszej i środkowej epoki kamienia na stanowisku $1 \mathrm{w}$ Aleksandrowie Łódzkim w kontekście analizy środowiska naturalnego. Łódź: 11-36.

Matuszkiewicz J.M., 1993. Krajobrazy roślinne i regiony geobotaniczne Polski, Prace Geograficzne IGiPZ PAN 158.

Nowaczyk B., 1986. Wiek wydm, ich cechy granulometryczne i strukturalne a schemat cyrkulacji atmosferycznej w Polsce w późnym vistulianie i holocenie. Wydawnictwo Naukowe Uniwersytetu im. A. Mickiewicza. Ser. Geografia 28: 1-245.

Pecio E., Kern E. (red.), 1988. Mapa glebowo-rolnicza - woj. konińskie 1:100 000. Red. naukowy E. Witek. Instytut Uprawy, Nawożenia i Gleboznawstwa w Puławach.

Petera J., Forysiak J., 2004. The last ice sheet extent in Central Poland. Geological Quarterly 47(4): 574-578.

Racinowski R., Szczypek T., Wach T., 2001. Prezentacja i interpretacja wyników badań uziarnienia. Wydawnictwo Uniwersytetu Śląskiego, Katowice.

Ralska-Jasiewiczowa M., Starkel L., 1988. Record of the hydrological changes during the Holocene in the lake, mire and fluvial deposits of Poland. Folia Quaternaria 57: 91-127.

Ralska-Jasiewiczowa W., 1966. Osady denne Jeziora Mikołajskiego na Pojezierzu Mazurskim w świetle badań. Acta Palaeobotanica 2.

Rotnicki K. 1972. Wiek najniższych poziomów terasowych doliny dolnej Prosny w kotlinie Pyzdrskiej w świetle wyników analizy osadów organicznych leżących w stropie terasy VII. Sprawozdania PTPN 90(2): 107-109.

Stankowski W., 1959. Wydma Ciemierowska w Kotlinie Pyzdrskiej. Badania Fizjograficzne nad Polską Zachodnią 5: 129-139. 
Stankowski W., 1963. Rzeźba eoliczna Polski północno-zachodniej na podstawie wybranych obszarów. PTPN, Prace Komisji Geograficzno-Geologicznej 4(1)

Stankowski W., Biedrowski Z., Stankowska A., Kołodziej K., Widera M., Wilkosz P., 1995. Litologia i stratygrafia kenozoiku okolic Konina. Przegląd Geologiczny 43(7): 559-564.

Stankowski W., Krzyszkowski D., 1991. Stratygrafia czwartorzędu okolic Konina. W: Przemiany środowiska geograficznego obszaru Konin-Turek. Wyniki realizacji Programu RR.II.14, w okresie 19861990. Instytut Badań Czwartorzędu UAM, Poznań: 12-31.

Starkel L., 2011. Present-day events and the evaluation of Holocene palaeoclimatic proxy data. Quaternary International 229: 2-7.

Tobolski K., 1966. Późnoglacjalna i holoceńska historia roślinności na obszarze wydmowym w dolinie środkowej Prosny. PTPN, Prace Komisji Biologicznej 32(1).
Trzeciakowski L., 1964. Warunki geologiczne stanowisk neolitycznych w dolinie Warty na odcinku pod Koninem. Archeologia Polski 9(2): 351-367.

Twardy J., 2008. Transformacja rzeźby centralnej części Polski środkowej w warunkach antropopresji. Wyd. UŁ, Łódź: 1-292.

Twardy J., 2011. Infulence of man and climate changes on relief and geological structure transformation in central Poland since the Neolithic. Geographia Polonica, 84, spec. issue, 1: 163-178.

Weng H.X., Hang X.M., Chen X.H. Wu N.Y., 2003. The stability of the relative content ratios of $\mathrm{Cu}, \mathrm{Pb}, \mathrm{Zn}$ in soils and sediment. Environmental Geology 45(1): 79-85.

Widera M., 2009. Geologia kenozoiku Niżu Polskiego. Przewodnik do ćwiczeń terenowych z geologii kenozoiku i geomorfologii. Wydawnictwo Naukowe UAM.

Zgłobicki W., 2008. Geochemiczny zapis działalności człowieka w osadach stokowych i rzecznych. Wydawnictwo UMCS, Lublin. 